\title{
A Combined Model for Effective Leadership in Technology Acceptance
}

Alireza Amini ${ }^{1}$ Assistant Professor, Faculty of Economics, Management and Social Sciences, Shiraz University, Iran.

Moslemali Mohammadloo ${ }^{2}$ Associate Professor, Faculty of Economics, Management and Social Sciences, Shiraz University, Iran.

Abbass Jafari ${ }^{3}$ M.A. in Student Business Management, Shiraz University, Iran (Corresponding Author).
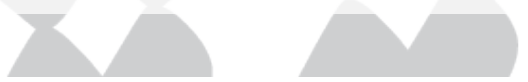

\begin{abstract}
Technology transfer and the employees' inclination to accept it is not always an easy process as they tend to be resistant to it. This paper intended to use leadership styles to present a model which could facilitate technology application by employees. The research was conducted in two phases: in phase one, technology acceptance criteria were identified and graded from the most relevant to the least relevant by ten experts selected from among Iranian university professors and defense industry specialists. Then, based on the acquired weights and by using Multimoora method, leadership styles indexes were prioritized. In the second phase, with the help of the same experts, indexes with higher grades were classified and relations among them were determined by applying interpretive structural modeling technique. Findings show that strategic leadership orientation, ability to establish leader communication and leader's decisiveness are the most effective in facilitating employee's technology acceptance.
\end{abstract}

Keywords: Technology Performance Expectation, Technology Effort Forecast, Technology Facilitating Effect, Social Influence; Leadership Style, Multi-criteria Decision Making.

1. alirezaamini@shirazu.ac.ir

2.mslmaml@shirazu.ac.ir

3. S.jafari@rose.shirazu.ac.ir 


\section{عنوان مقاله: ارائه مدل تلفيقى رهبرى اثرگذار در يذيرش فناورى \\ عليرضا امينى' ـمسلم علىمحمدلو 'عباس جعفرى'

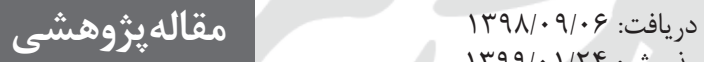

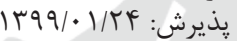

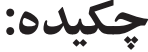

انتقال فناورى و استفاده از آن توسط كار كنان هميشه بلر احتى انجام نمى شود و همواره

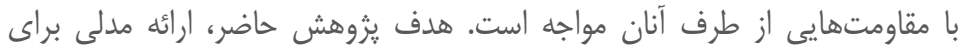

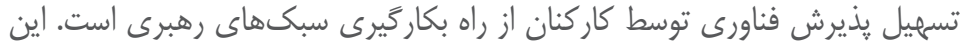

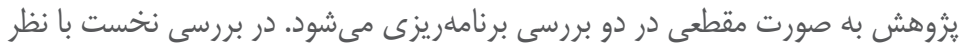

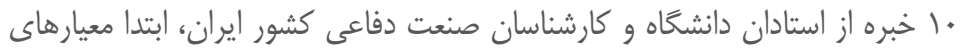

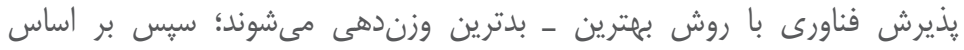

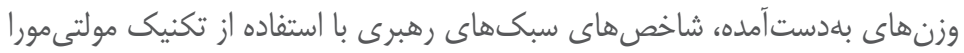

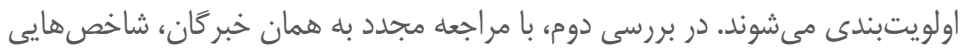

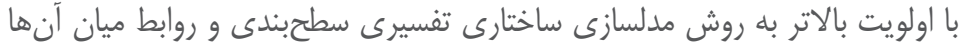

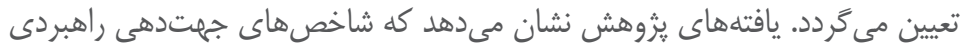

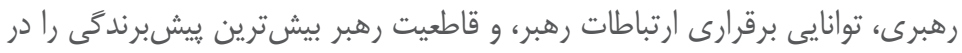
تسهيل يذيرش فناورى كاركنان دارند.

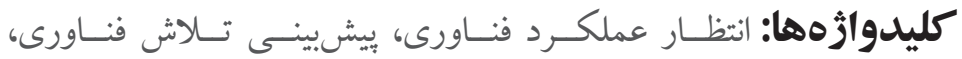

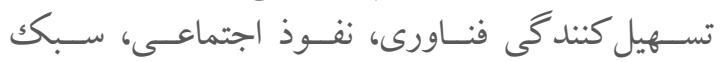

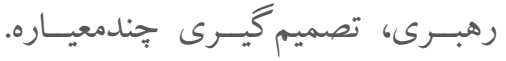

azalirezaamini@shirazu.ac.ir

1. استاديار دانشكده اقتصاد، مديريت و علوم اجتماعى، دانشكاه شيراز، ايران. mslmaml@shirazu.ac.ir

r. دانشيار دانشكده اقتصاد، مديريت و علوم اجتماعى، دانشكاه شيراز، ايران. S.jafari@rose.shirazu.ac.ir

$$
\text { r. دانشجوى كارشناسى ارشد مديريت كسبو كار، دانشاه شيراز، ايران (نويسنده مسئول). }
$$




\section{مقام}

دليل و جَّونگَى اثرگذارى يك مدير به عنوان يك رهبر در سازمان، هميشه از مباحث مهم

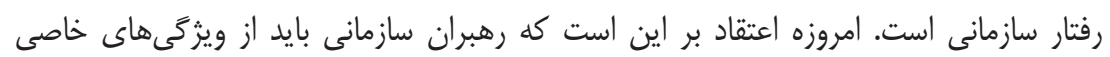

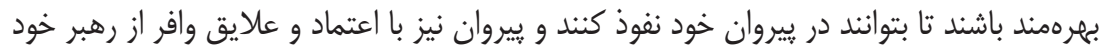

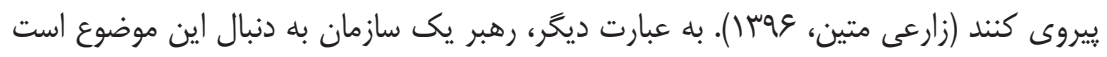

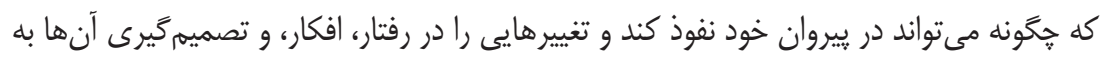
نفع منافع سازمان بلوجود آورد. از جمله موضوعهايى كه رهبر با شناخت و نفوذ خود در آن مىتواند

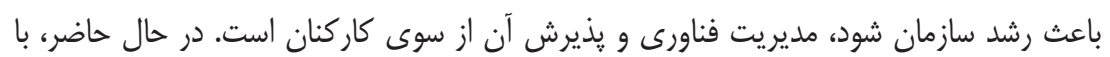
توجه به نياز جامعه و سازمانهاى امروز به نوآورى و تغييرهاى فناورانه، به رهبرانى با مدلهاى فكرى و رفتارى جديدى نياز است كه بتوانند بر اساس دانش مبتنى بر واقعيتها، تحولهاى

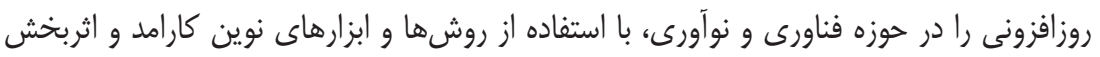

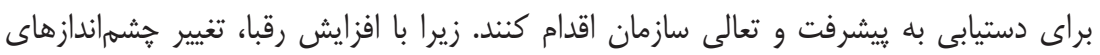

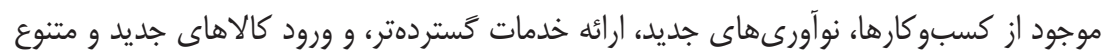
به بازار، هر سازمانى ايجاد فناورىهاى جديد را در فرايندهاى سازمانى خود حس مى كند تا در بازار باقى بماند و مزيت رقابتى خود را حفظ كند. از مهمترين ويثزى هاى فناورىهاى جديد، سرعت زياد در يردازش دادهها، دقت فوقالعاده زياد، سرعت بالاى دسترسى به اطلاعات، بهروز بودن،

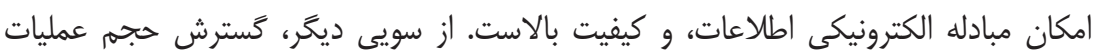
و ييجيدهتر شدن امور مربوط به كسبوكارها استفاده از اين فناورىها را اجتنابنايذير مى كند.

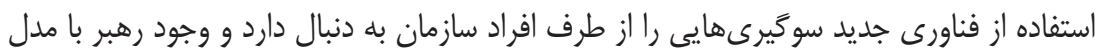

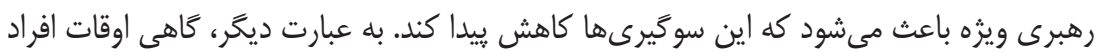

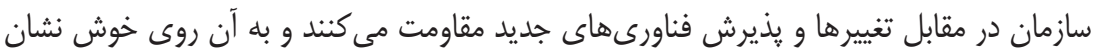
نمى دهند. به همين دليل، معرفى فناورىهاى جديد در يك سازمان بههيجوجه كار سادهاى نيست و קالش هايى همجون يذيرش نكردن كاركنان را به همراه دارد (Schepers et al., 2005). در واقع، با وجود مصرف هزينههاى هنحَفت و سرمايهَذارى براى توليد يا خريد و انتقال فناورى، يزوهشهان نشان مىدهند كه كاربران با وجود دسترسى به فناورىهاى جديد از آنها استفاده نمى كنند، 
به اين معنا كه فناورىهاى جديد مورد يذيرش آنان قرار نمى يرند (Wang et al., 2003).

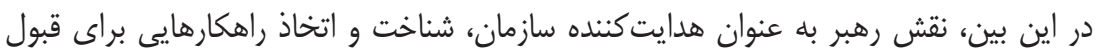

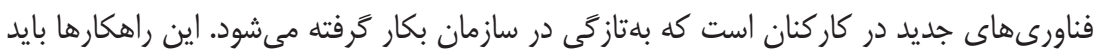

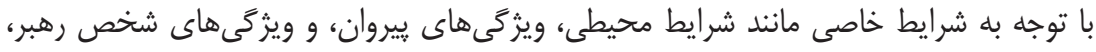

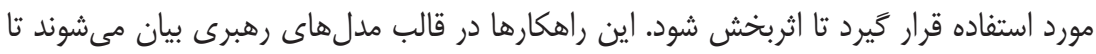

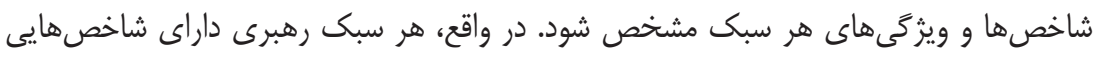

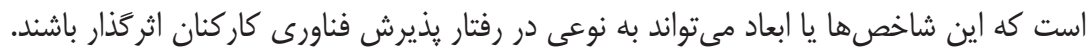

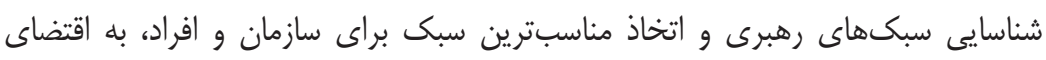

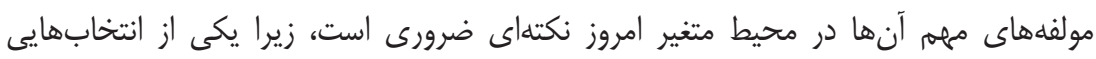

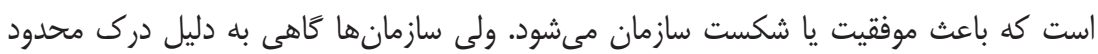

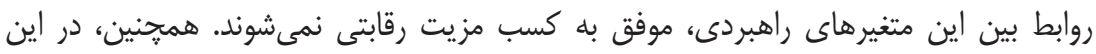

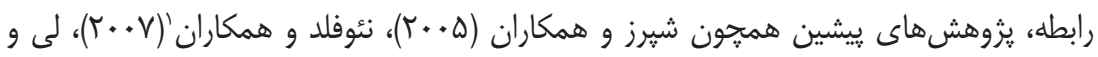

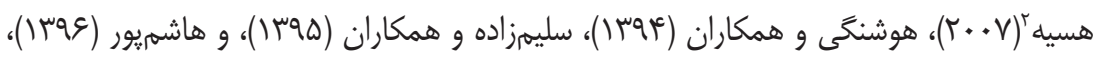

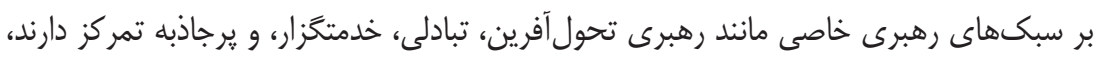

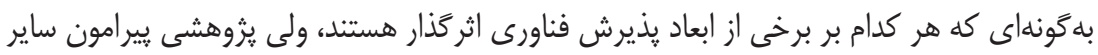

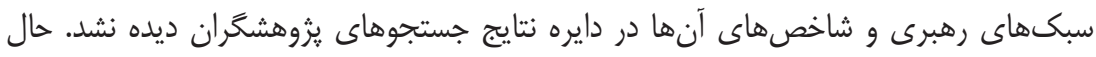

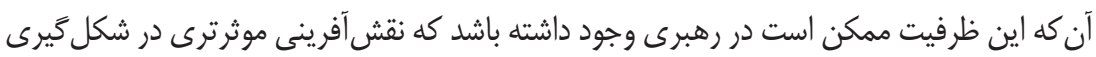

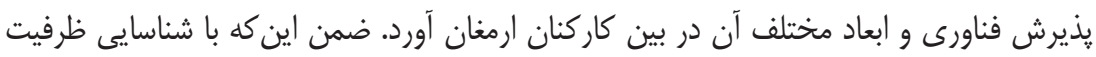

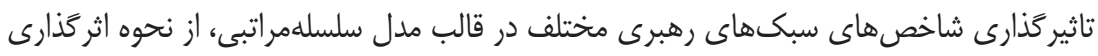

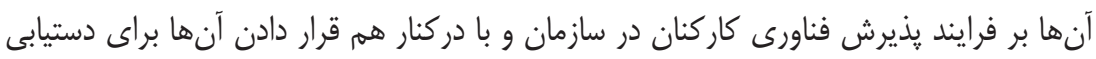

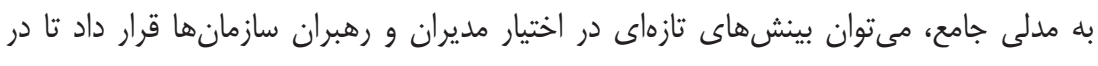

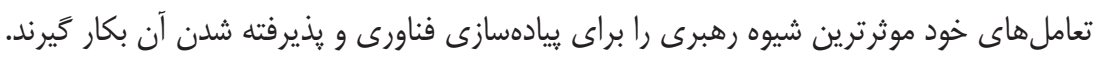

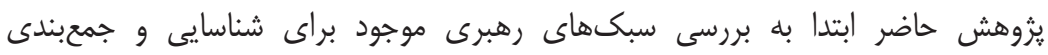

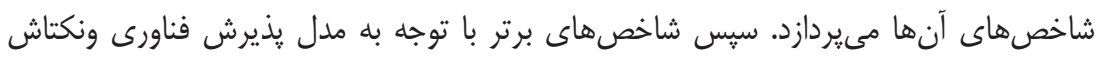

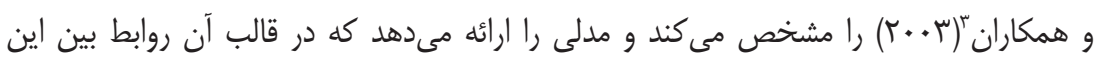

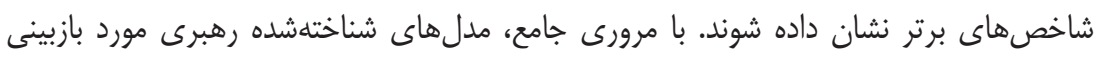

1. Neufeld et al.

2. Li \& Hsieh

3. Venkatesh et al. 
و شاخصهاى هر كدام مورد بازخوانش قرار مى گيرند تا بتوان با اولويتبندى آنها مدلى

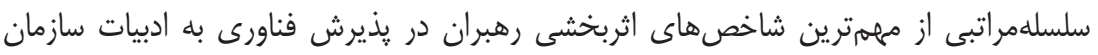

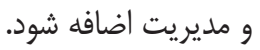

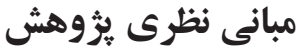

در دهه اخير، بزوهشهاى اندكى در حوزه مديريت و رهبرى صورت كرفته كه به عوامل موثر در رفتار يذيرش اشاره داشته و استفاده از يك فناورى را تحت تاثير قرار داده، كه همين موضوع باعث شكل گيرى مدلهاى نادرى در اين زمينه شده است. از ميان اين مدلهاى موجودة

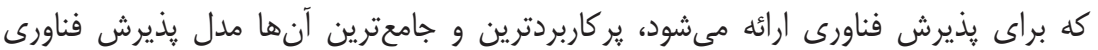

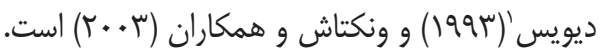

\section{يذيرش فناورى}

يذيرش، يديدهاى קندبُعدى است و مجموعه وسيعى از متغيرهاى كليدى مانند ادراكها،

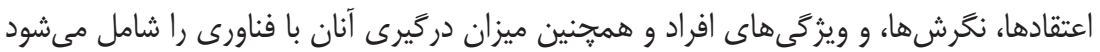

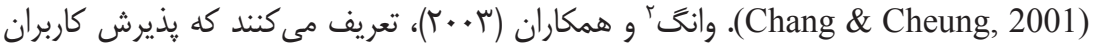
علاقه مشهود بين يك گروه براى استفاده از فناورى اطلاعات است، به منظور انجام وظايفى كه اين فناورىها براى يشتيبانى از آنها طراحى شدهاند. بسيارى، از يزوهشكَران بر اين باورند كه إنهات

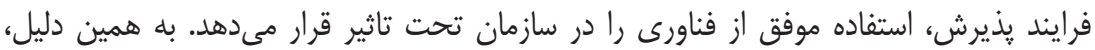
بررسى عوامل موثر بر يذيرش فناورىها در سازمان، كانون توجه اين دانشمندان قرار مى گئيرد

.(Liao et al., 2009)

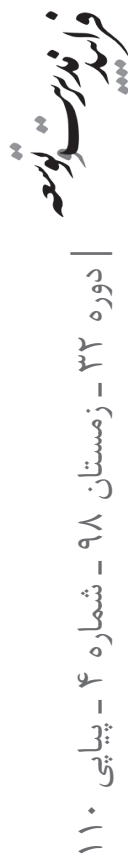

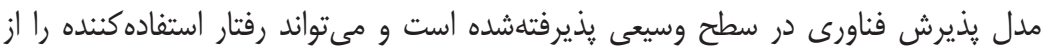
بين كل جمعيت استفادهكندكان توصيف كند (Lee et al., 2003). اين نظريه بيان مى كند كه

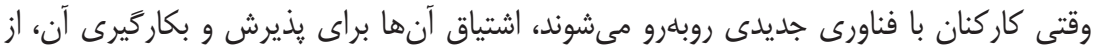

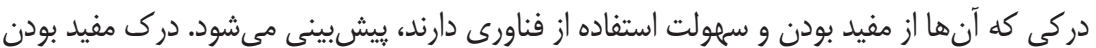

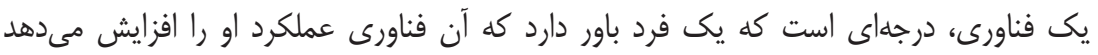
(Hayashi et al., 2004)

1. Davis

2. Wang 
فناورى، توسط افرادى كه از اين فناورى استفاده مى كنند، يكى از عوامل اثركذار بر موفقيت سازمان

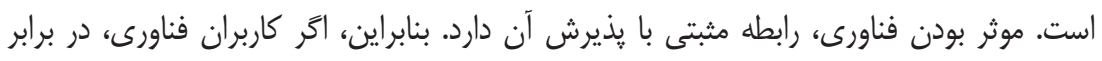

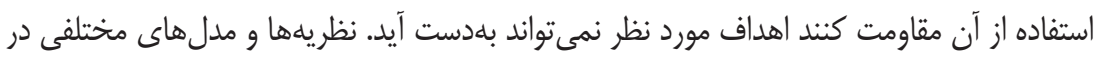

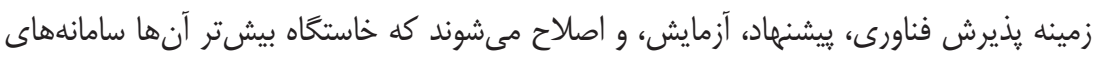

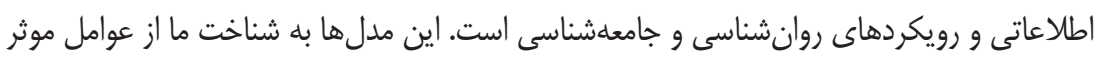
در يذيرش فناورى از سوى كاربران و روابط بين آنها كمى مى كنند (Sun \& Zhang, 2006).

\section{مدلهاى يذيرش فناورى}

اثر كذارى موضوع بذيرش فناورى، وابستخى زيادى به شناخت عوامل اثر كذار بر آن دارد كه در

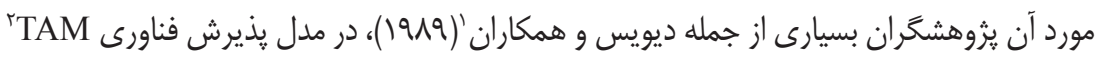

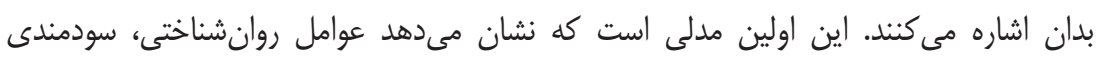

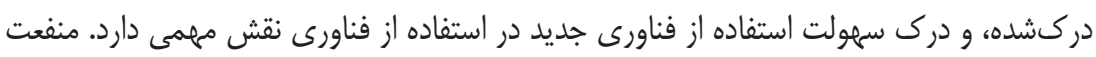

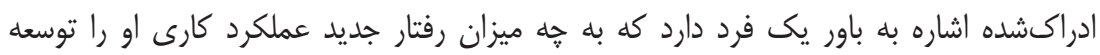

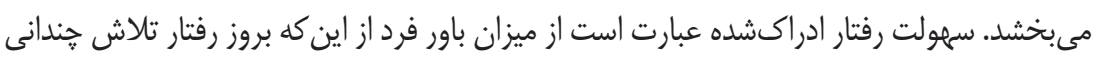

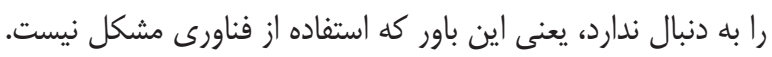

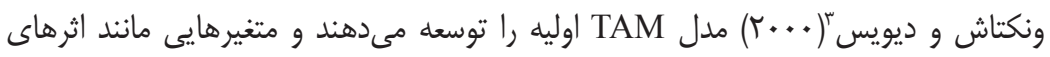

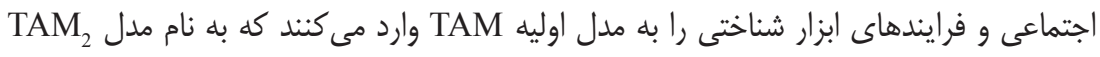

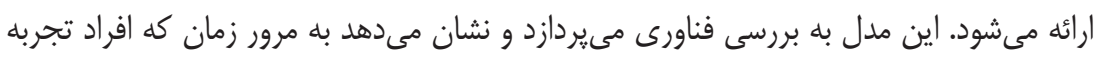

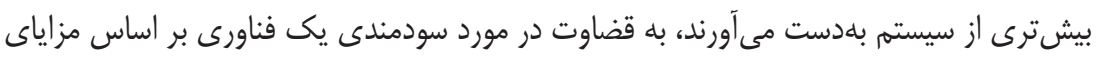

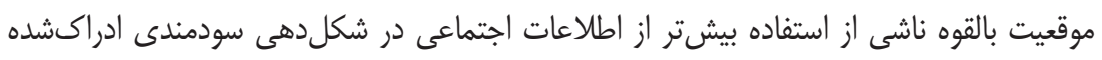

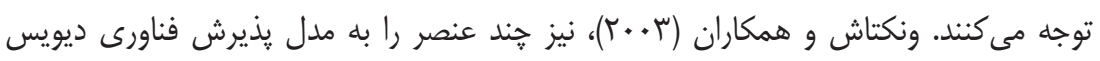

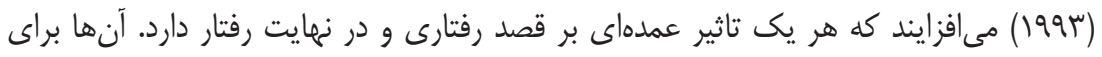

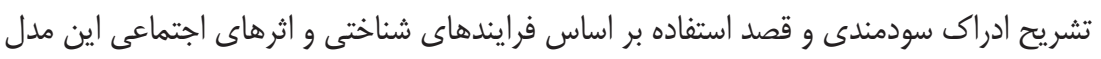
را توسعه مى دهند.

بر اساس ثزوهشهاى ييشين، جهار عنصر مههم در شكل

1. Davis et al.

2. Technology Acceptance Model

3. Venkatesh \& Davis 
عبارتاند از ييشبينى عملكرد، ييشيينى تلاش، نفوذ اجتماعى، و تسهيل شرايط. آنها بيشيبينى

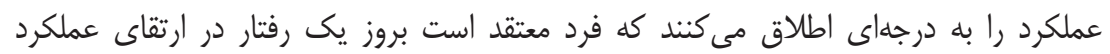
حرفهاى او سودمند خواهد بود. بيشبينى تلاش نيز به درجه سهولت رفتار اطلاق مى ديود. نفوذ

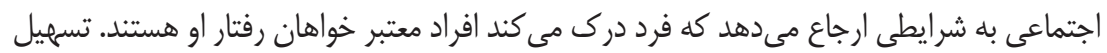

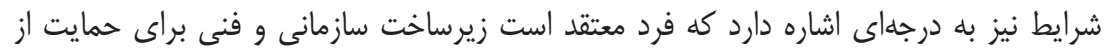

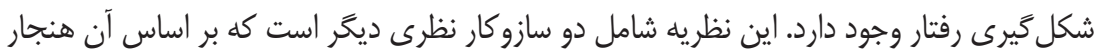

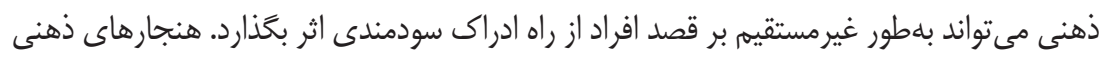

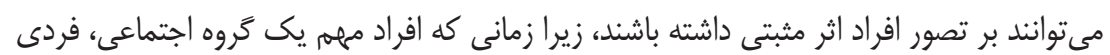

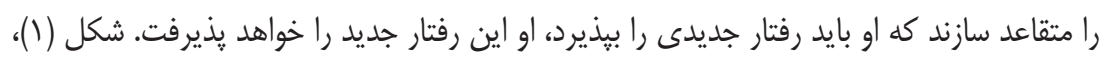
عناصر اين نظريه را در قالب مدلى منسجم نشان مئد ردهد.

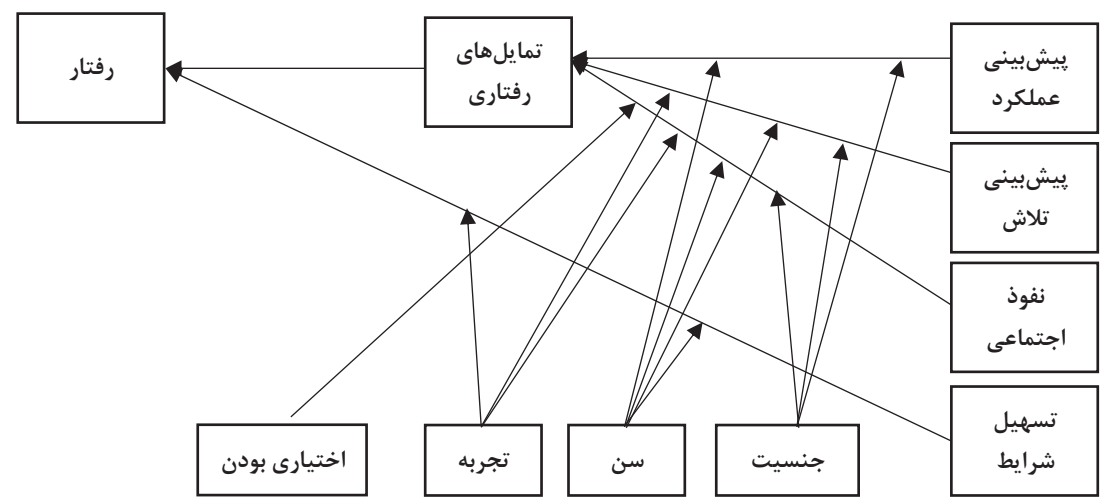

شكل ا: نظريه يكيارجه يذيرش و استفاده از فناورى (Venkatesh et al., 2003)

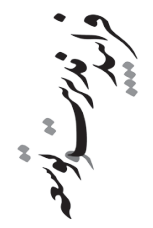

ते

ธิ

ले

با توجه به مدلهاى يركاربرد موجود، يكى از جامعترين و ير كاربردترين آنها مدل يذيرش فناورى ونكتاش و همكاران (r +. r) است كه در شكل (1) مشاهده مىشود، و در اين يزوهش از

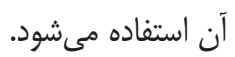




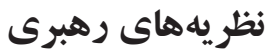

رهبرى، يكى از جامعترين فرايندهاى نفوذ اجتماعى در علوم رفتارى شناخته مىشود (محمدى

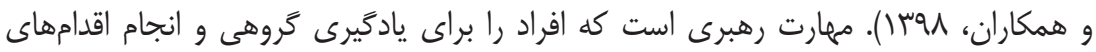

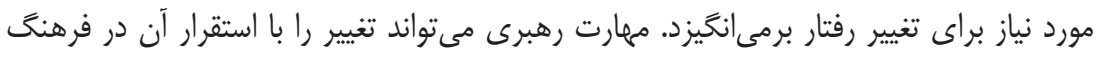

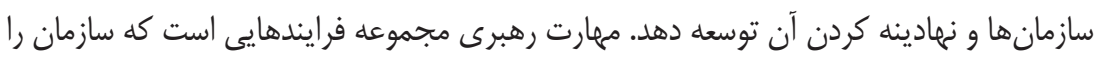
با تغيير شرايط ساز كار مى كند، و آن را در موقعيت برتر قرار مىدهد، براى آينده سازمان جشمهاندانداز

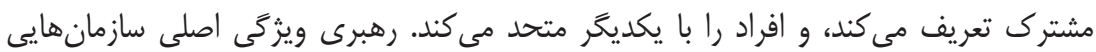

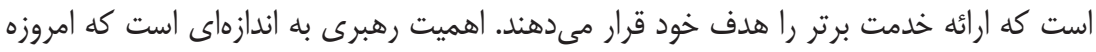
دانشمندان بيان مى كنند كه كليد خلق و بقاى سازمانهاى موفق قرن بيستويكم رهبرى است،

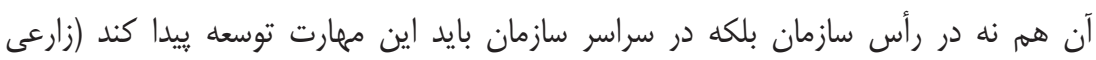

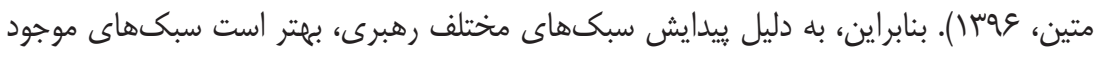

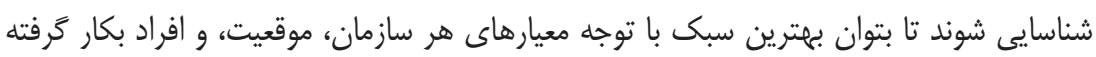

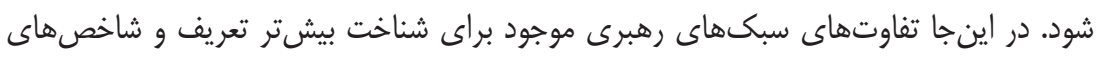
آنها معرفى مىشوند.

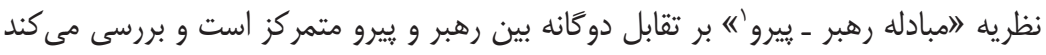

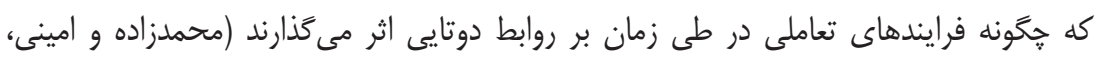

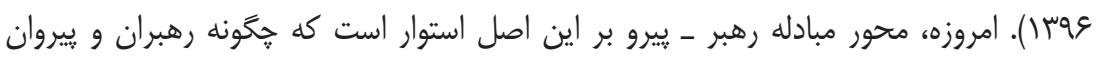

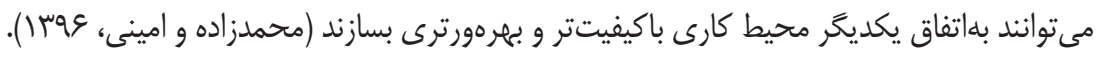

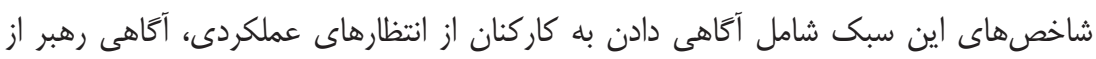

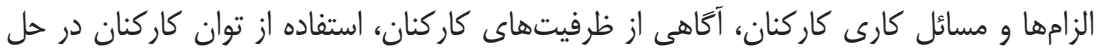

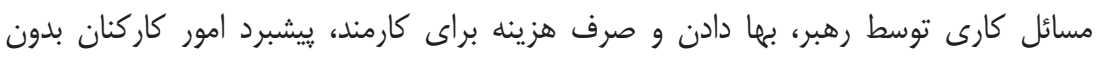
ضرورت حضور رهبر، و روابط كارى قوى كاركنان با رهبر است (Graen \& Uhl-Bien, 1995).

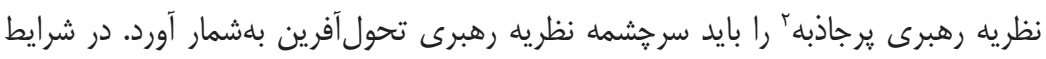

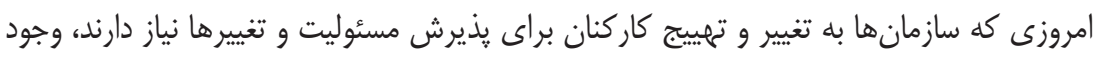

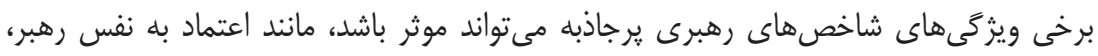

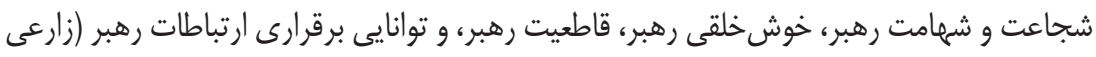

1. Leader-Member Exchange (LMX)

2. Charismatic Leadership 


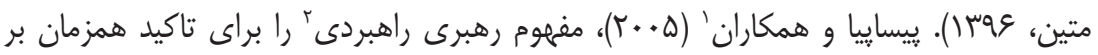
انعطافيذيرى و عمل كرايى در رهبرى ارائه مىدهند و آن را توانيى براى اتخاذ تصميم درباره

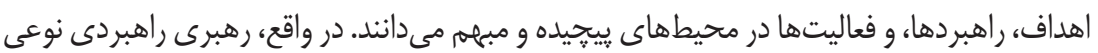

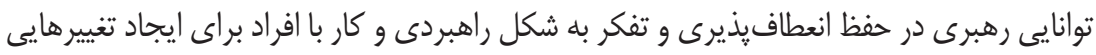

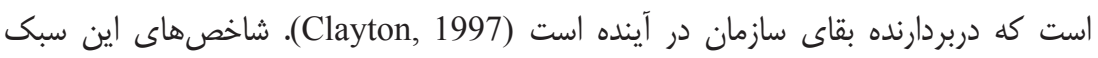
جهتدهى راهبردى رهبرى، استفاده رهبر از قابليتهاى كليدى، توسعه سرمايه انسانى، برقرارى

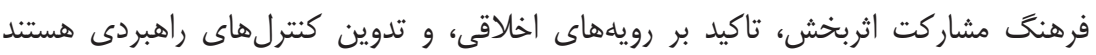

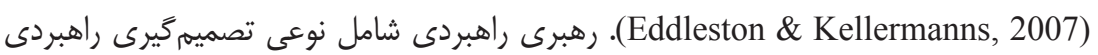

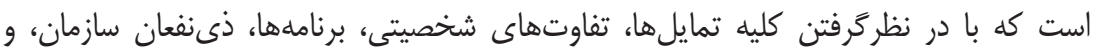

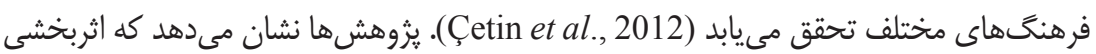

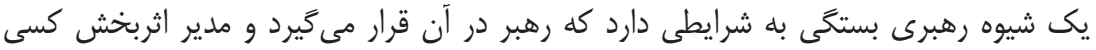

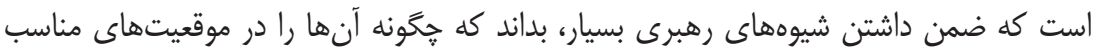

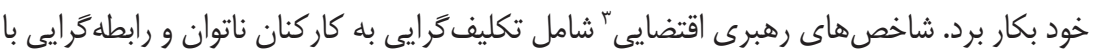

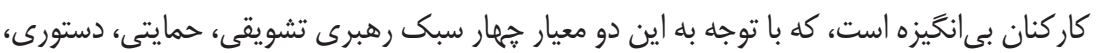
و تفويضى شكل مى گيرد (زارعى متين، عوسار).

توانمندسازى به معنى احساس مسئوليت و پاسخكَويى بيشتر كاركنان براى بهيبود عملكرد

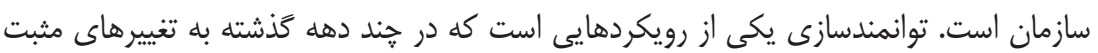
فراوانى در اجراى فعاليتهاى كاركنان منجر شده است (Miri et al., 2011). از شاخصهاى إنى

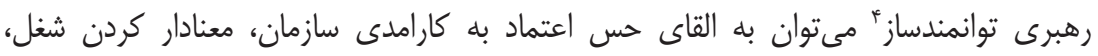

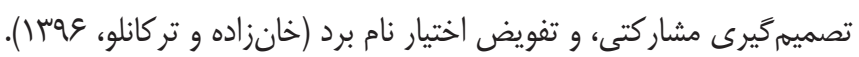

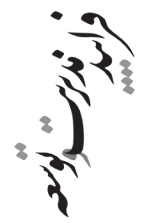

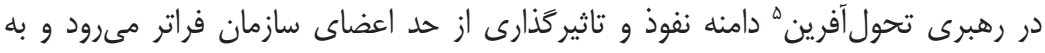
ايجاد دَّر كَنى و تحول در كل شالوده و فرهنگ سازمانى مى انجامد. در واقع، رهبران تحول آفرين

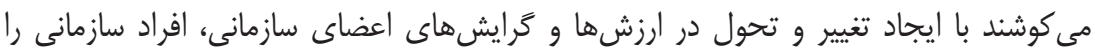

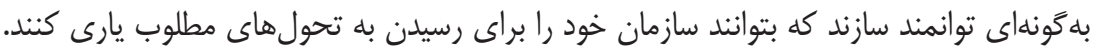

1. Pisapia et al.

2. Strategic Leadership

3. Situational Leadership

4. Empowering Leadership

5. Transformational Leadership 
شاخصهاى اين سبك رهبرى ترغيب ابتكار و خلاقيت كاركنان، كاريزما يا نفوذ آرمانى رهبر،

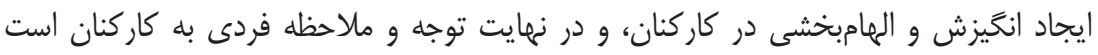

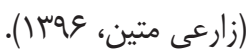

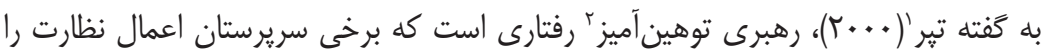
با بىاحترامى، فحاشى، و سوء استفاده از زيردستان خود نشان مىدهند. اين رفتار در سه فاز ايجاد تنش، رخ دادن اتفاق شديد بين سريرست و زيردست، و مهربانى و تظاهر به رفتار غلط در اينان

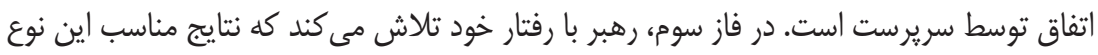
سريرستى را ترويج كند تا سبب بروز رفتار "خوب" توسط كاركنان شود. جنين رفتار "خوبى" كاه

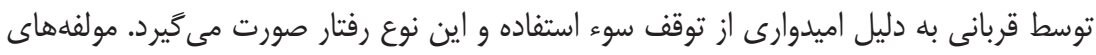

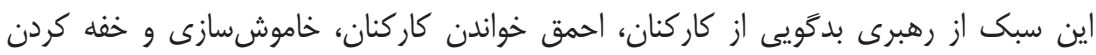
كاركنان، محدود كردن ارتباطات كاركنان، خالى كردن خشم بر كاركنان، سوء استفاده از نقاط

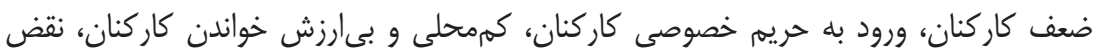

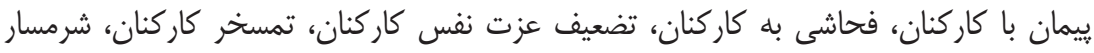
كردن كاركنان، و كوجى كردن افراد در جمع است (Tepper, 2000). دغدغه مشترى را داشتن، مهمترين عامل موفقيت در هر موسسهاى است، زيرا مشترى

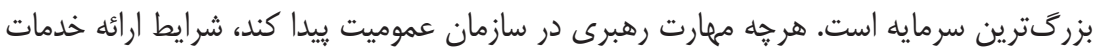

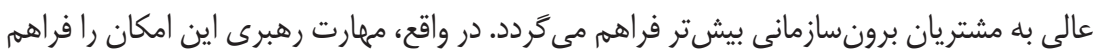

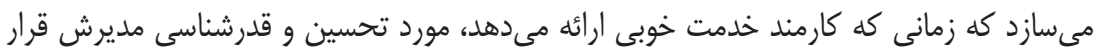

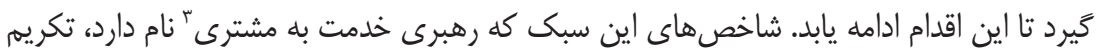

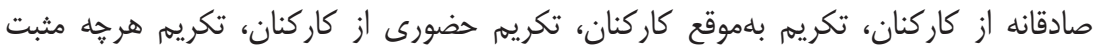

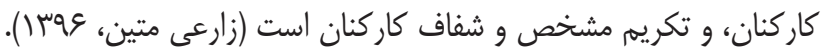

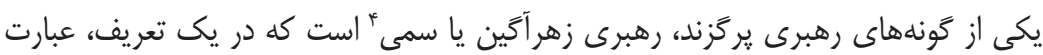

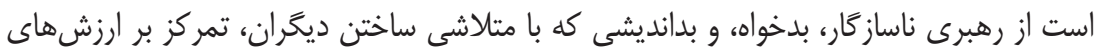

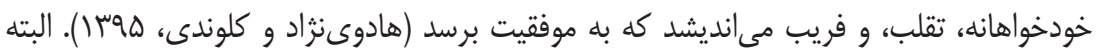

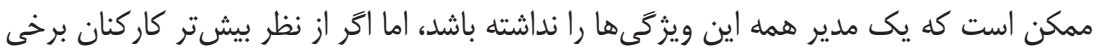

1. Tepper

2. Offensive Leadership

3. Employee Customer Service Leadership

4. Toxic Leadership 
از اين ويثَى ها را داشته باشد، آن را مديرى داراى سبك زهر آَين مىنامند. شاخصهاى اين

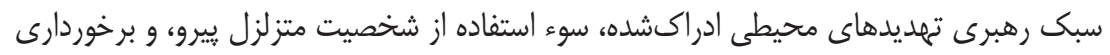

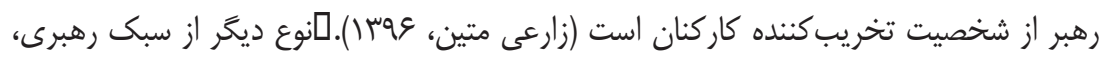

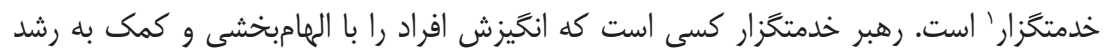

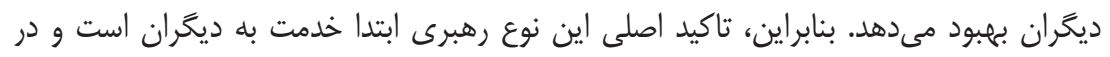

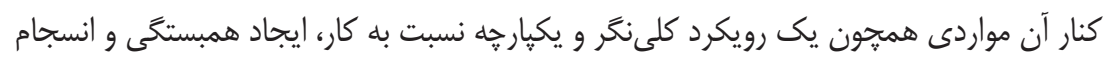

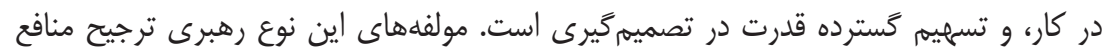

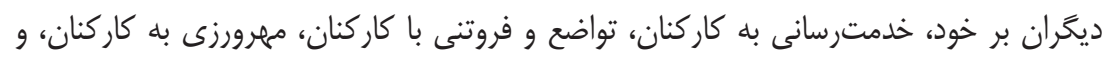

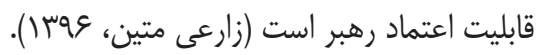

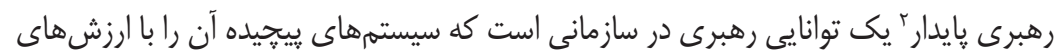

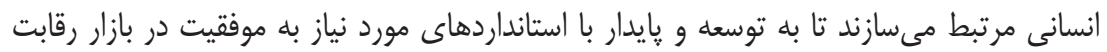

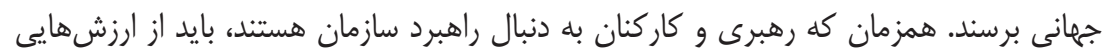

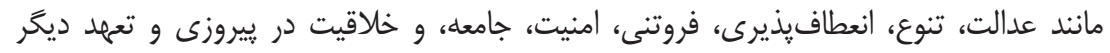

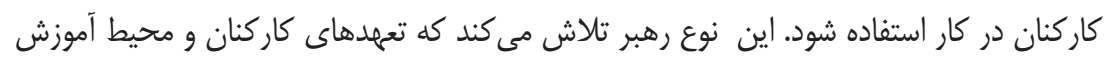

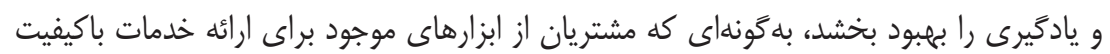

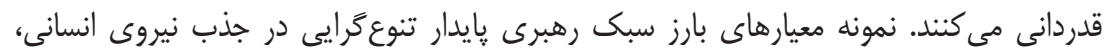

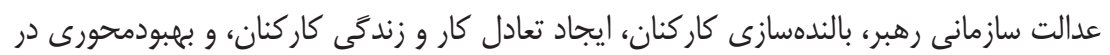
عين ييشرفت كار است (Farooq et al., 2017).

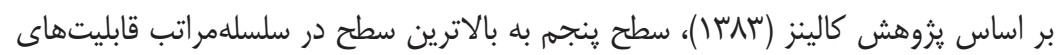

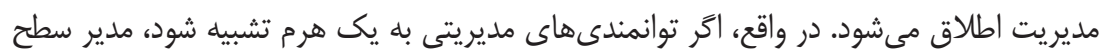

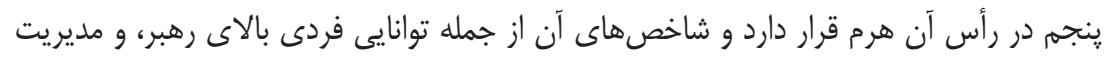

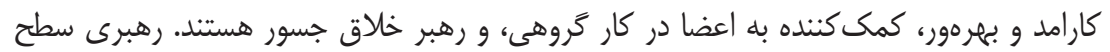

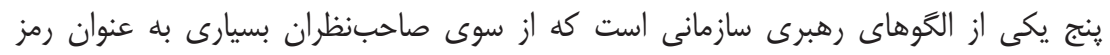

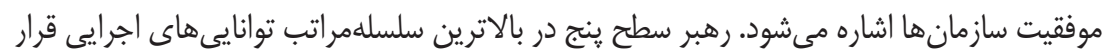

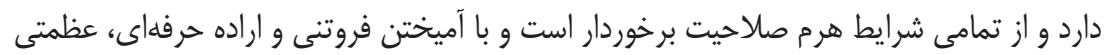

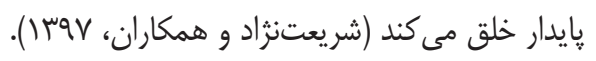

1. Servant Leadership

2. Sustainable Leadership 
امروزه رهبرى اخلاقى' به عنوان يك راهبرد پايه در عرصه مديريت و رهبرى سازمانها

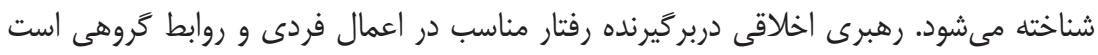

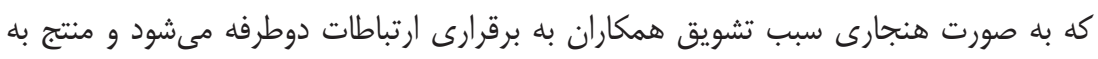
اتخاذ تصميمهاى مناسب مى كردد (Brown et al., 2005). در رهبرى اخلاقى حقوق و شأن

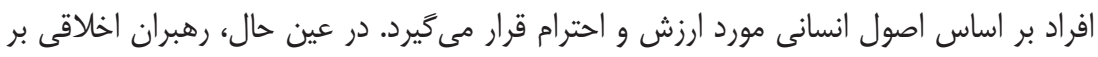

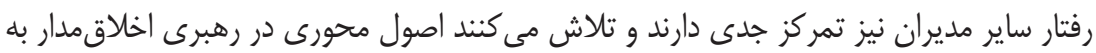

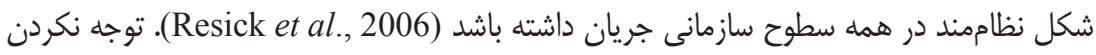

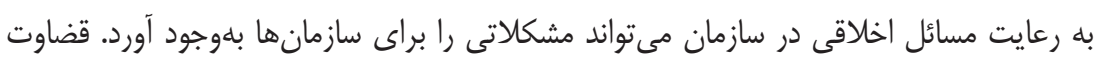

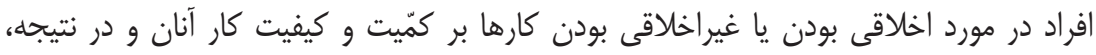

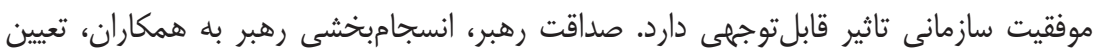

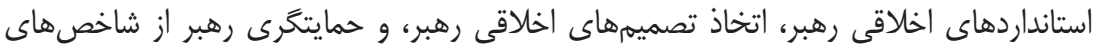
اين نوع رهبرى هستند (Avey et al., 2011).

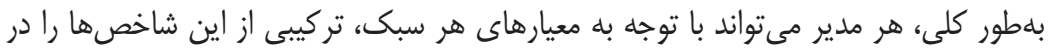

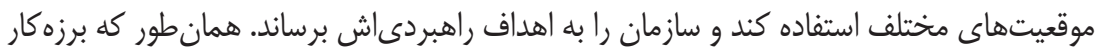

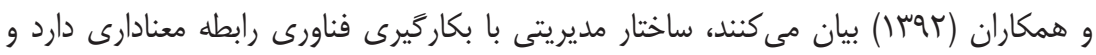
عوامل سازمانى از مهمترين عوامل در بكاركيرى فناورى بهشمار مىروند. براى مثال، منطبق بر بران

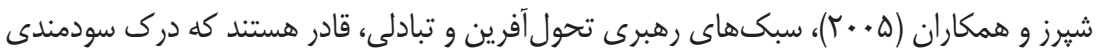

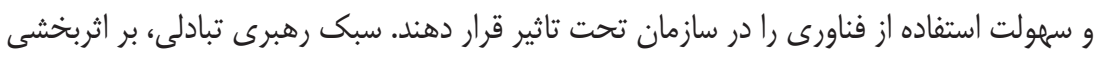

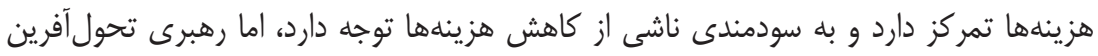

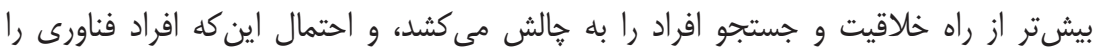

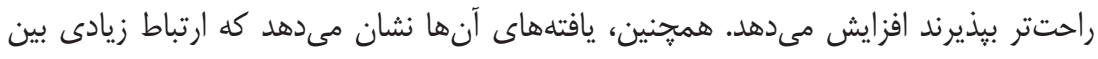

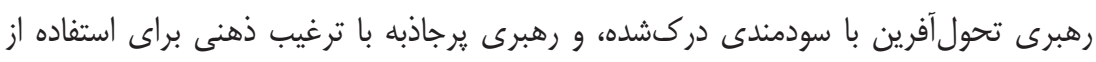

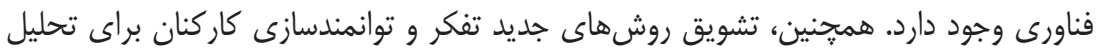

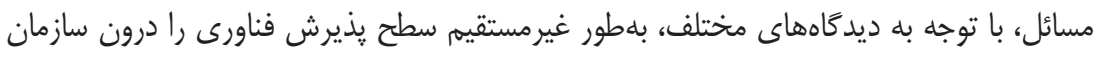

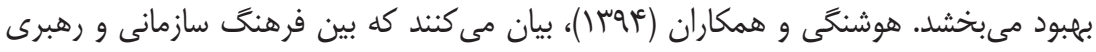

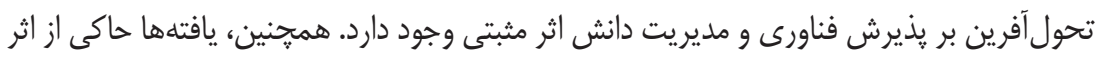

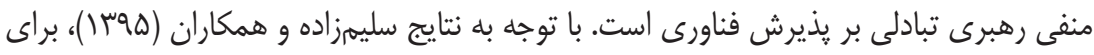

1. Ethical Leadership 
بررسى نقش رهبرى تحولآفرين در تسهيل نوآورى، مشخص مىشود كه بين رهبرى تحول آفرين و تسميل نوآورى و فرهنَ نوآورى، و همجنين ابعاد رهبرى تحولآفرين (ترغيب ذهنى، نفوذ آرمانى، المعامبخشى، و ملاحظه فردى) با تسهيل نوآورى رابطه معنادارى وجود دارد. لى و هسيه

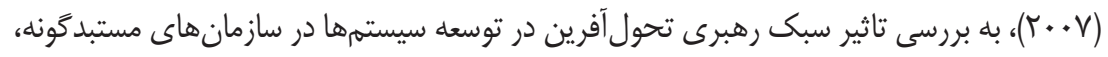

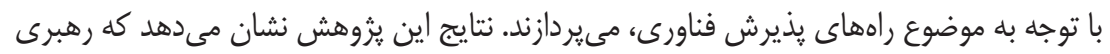

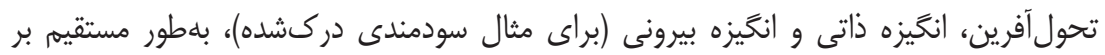

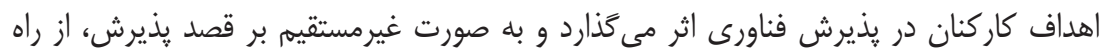
افزايش انخيزه درونى افراد اثر كذار است.

با توجه به يزوهش هايى كه بررسى مى شود، به نظر مىرسد كه كَاه برخى از سبكهاى رهبى رهبرى در كاركنان سازمانى اثر بيشتر و در كاركنان سازمان ديخرى اثر كمترى دارند. براى مثال، نئوفلد

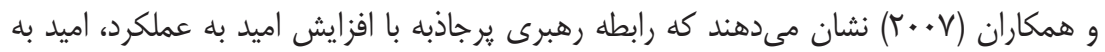

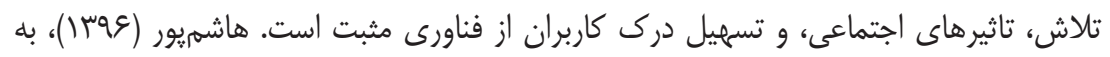
تاثير يذيرش فناورى اطلاعات بر قصد اشتراكگذارى دانش، با در نظرگرفتن نقش تعديل سبك رهبرى مىيردازد و نشان مىدهد كه سطح مشاركت كاركنان در فعاليتهاى فناورى لدي

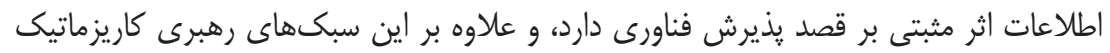
و عملياتى نقش تعديلگرى بر رابطه بين قصد يذيرش فناورى اطلاعات بين كاركنان سازمان

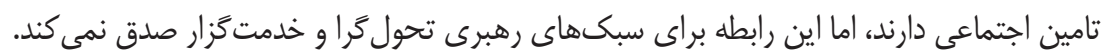

\section{روش}

هدف اين يزوهش، ارائه مدل تلفيقى از رهبرى اثر گذار در يذيرش فناورىهاى جديد توسط

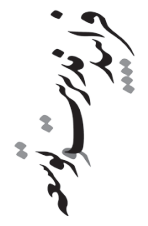

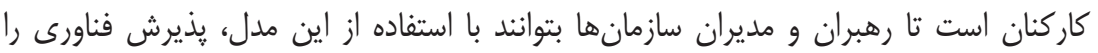
در سازمان تسهيل كنند. اين يزوهش از لحاظ هدف، كاربردى است و جامعه آمارى آن استادان دانشگًاه و كارشناسان صنعت دفاعى كشور است. نمونه گيرى يزوهش حاضر به صورت هدفمند قضاوتى است و نمونهايى انتخاب مىشوند كه يا در حوزه فناورى و رهبرى صاحبنظر باشند يا دست كم سه سال در فعاليتهاى مرتبط سابقه داشته باشند. حجم نمونه در تصميمَيرى گروهى با استفاده از نظر خبركان، بايد دستكم • ا نفر (Mullen, 2003)، يا بين ^ تا זا نفر باشد

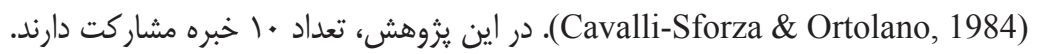
صنعت دفاعى يكى از مهمترين صنايع كشور است كه تحقيقوتوسعه و استفاده از فناورىهاى 
جديد در آن بسيار مورد توجه است، از اينرو موضوع يذيرش فناورى بايد با حساسيت بيشترى در

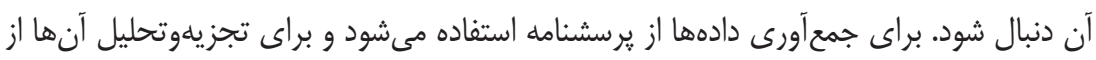

روشهاى تصميمَّيرى حندمعياره بهره كَرفته مىشود.

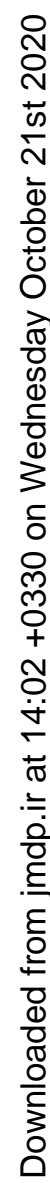

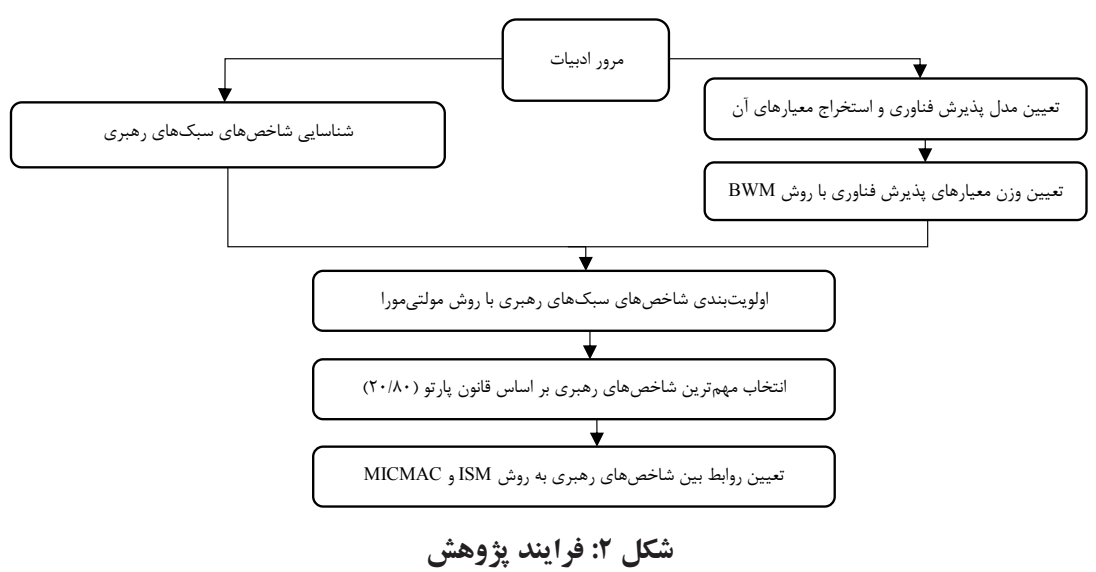

با توجه به شكل (Y)، براى وزندهى به معيارهاى مدل يذيرش فناورى ونكتاش و همكاران

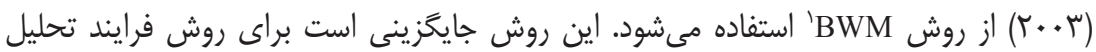

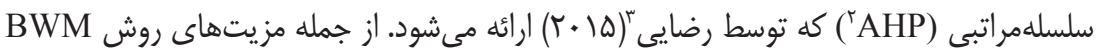

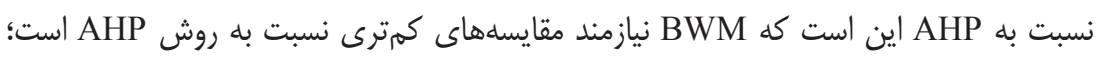

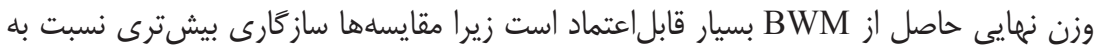
AHP فراهم مى كنند؛ و در ماتريس مقايسههاى زوجى در BWM تنها از اعداد صحيح استفاده مىشود كه استفاده از آن را بسيار سادهتر مى كند (Rezaei, 2015). از اينرو، يرسشنامهاى طبق استانداردهاى اين روش طراحى مى شیود، و ميان خبركان توزيع مى گردد تا وزن معيارها مشخص شود. سيس با استخراج شاخصهاى هر سبى رهبرى

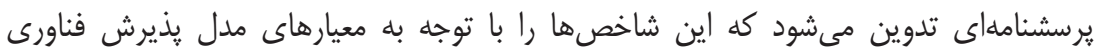

1. Best-Worst Method

2. Analytic Hierarchical Process

3. Rezaei 


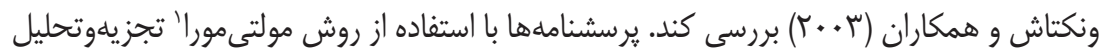

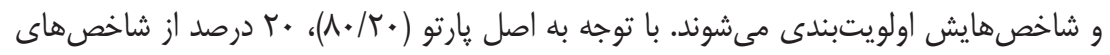

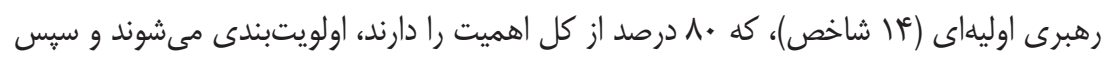

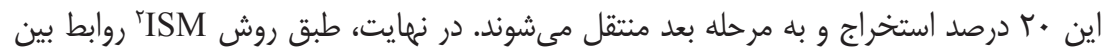

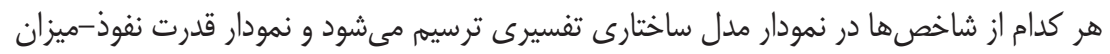

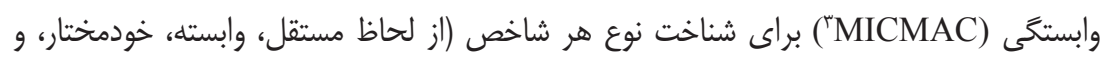

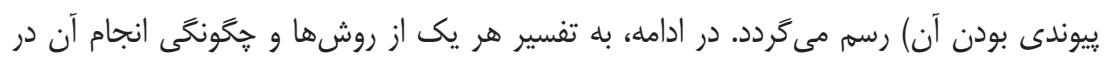

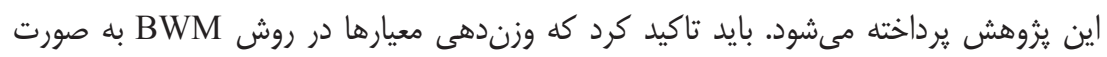

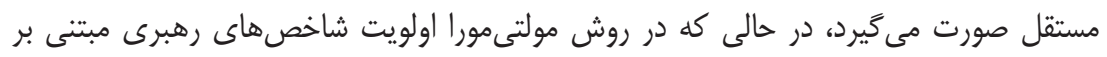

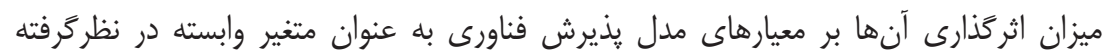

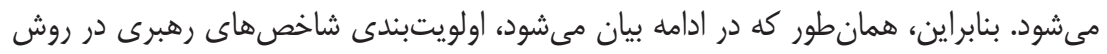

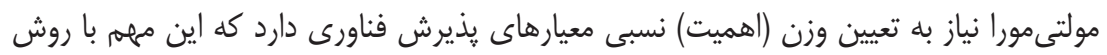
BWM تعيين مىشود.

\section{وزندهى به معيارهاى مدل پذيرش فناورى} بر اساس روش بهترين-بدترين (Rezaei, 2016)، بهترين و بدترين معيار به وسيله

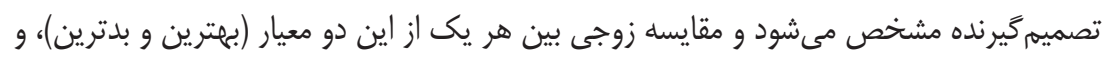

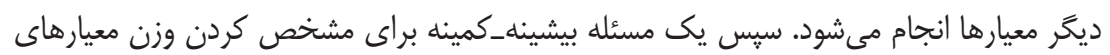
مختلف فرموله و حل مى مردد.

\section{كامهاى روش بهترين-بدترين}

كام يكم: مجموعه معيارهاى تصميمَّيرى تعيين مىشود. در اين كام، مجموعه معيارها به صورت

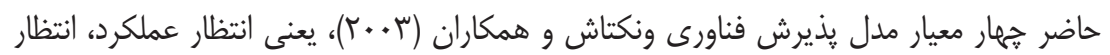
تلاش، نفوذ اجتماعى، و تسهيل شرايط به عنوان معيارهاى تصميمَّيرى مشخص مى شودا.

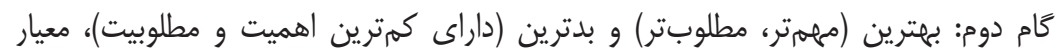

1. Multimoora

2. Interpretive Structural Modeling

3. Impact Matrix Cross-Reference Multiplication Applied to a Classification 
مشخص مى شود. در اين مرحله، تصميمَّيرنده بهترين و بدترين معيار را بلهور كلى تعريف مى كند و هيج مقايسهاى در اين مرحله صورت نمى مئيرد.

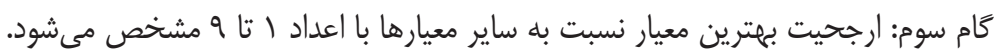

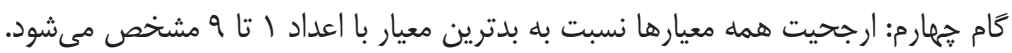

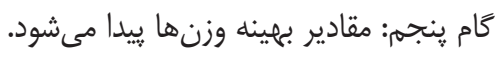

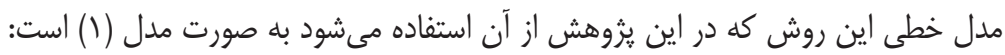
$\min \xi$

s.t.

$\mid \mathrm{w}_{\mathrm{B}}-\mathrm{a}_{\mathrm{Bj}} \mathrm{w}_{\mathrm{j}} \nmid \xi$, for all $j$

$\mid \mathrm{w}_{\mathrm{j}}-\mathrm{a}_{\mathrm{jw}} \mathrm{w}_{\mathrm{w}} \notin \xi$, for all $j$

$\sum_{j} w j=1$

$\mathrm{w}_{\mathrm{j}} \geq 0$, for all $j$

كام ششم: محاسبه نرخ ناساز كارى (هرجقدر مقدار نرخ ساز كارى به صفر نزديكتر باشد نتايج

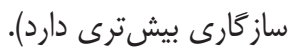

جدول ا: مقادير محاسبه نرخ ناساز كارى

\begin{tabular}{|c|c|c|c|c|c|c|c|c|c|}
\hline 9 & $\wedge$ & $\checkmark$ & 9 & 0 & f & $r$ & r & 1 & abw \\
\hline Q & $\varphi / 4 V$ & $r / v r$ & $\mu /$. & $T / \mu$. & $1 / 9 \pi$ & $1 / \cdots$ & $\cdot / 4 q$ & $\cdot / \cdot$ & شاخص ساز كارى \\
\hline
\end{tabular}

\section{رتبلدبندى شاخصهاى رهبرى}

روش مولتىمورا يك روش رتبهبندى است كه ززينهها را با استفاده سه روش نسبى، نقطه

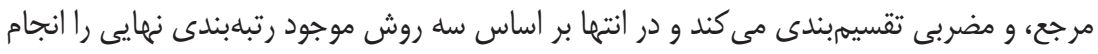

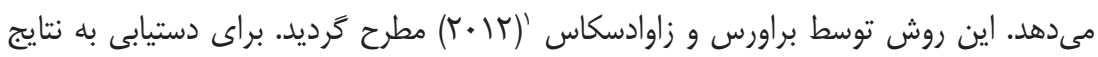
مولتىمورا كامهاى زير برداشته مى شودا.

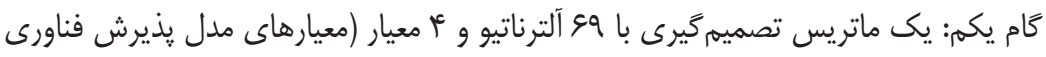

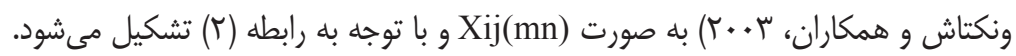

1. Brauers \& Zavadskas 
$X=\left[x_{i j}\right]_{n \times m}$

كام دوم: با كمى روش نرمالسازى بردارى، ماتريس R كه نرمالشده ماتريس Xij(mn) است، تشكيل داده مىشود. $r_{i j}=\frac{x_{i j}}{\sqrt{\sum_{i=1}^{m} x_{i j}^{2}}}, i=1,2, \ldots, m, j=1,2, \ldots, n$ كام سوم: ماتريس نرمالشده موزون از ضرب مقادير ماتريس نرمالشده در وزن معيارهاى

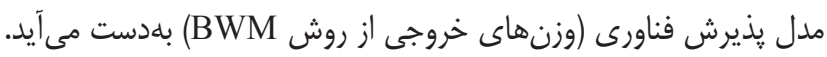
$X_{i j}^{*}=X_{i j}^{*}\left(r_{i j}\right)_{n \times m}$

كام هِهارم: در اين مرحله، الكوريتهم جمعى (سيستم نسبت) اجرا مىشود. بدين ترتيب كه

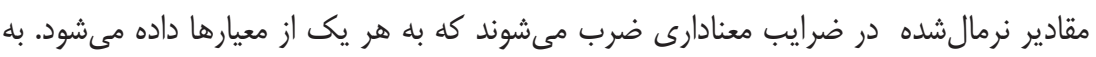

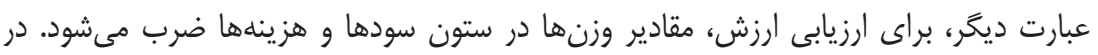

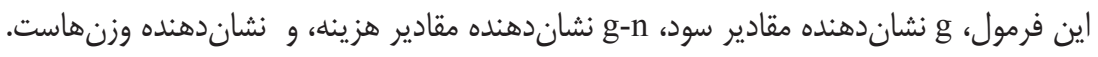
$y_{i}=\sum_{j=1}^{g} w_{j} x_{i j}^{*}-\sum_{j=g+1}^{n} w_{j} x_{i j}^{*}$

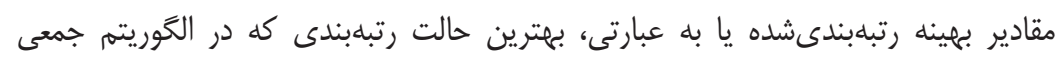
بلهدست آمده است، به صورت رابطة (ه) است.

$A_{R S}^{*}=\left\{A_{i} \mid \max _{i} y_{j}\right\}$
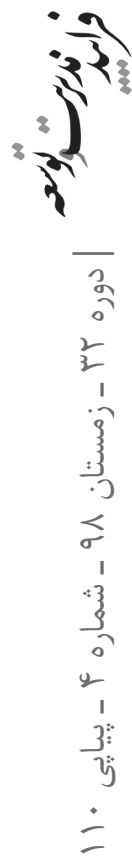

كام ينجم: استفاده از الكَوريتم نقطه مرجع. اين روش بر بايه دو مفهوم ويخگى بيشينهاى نقطه

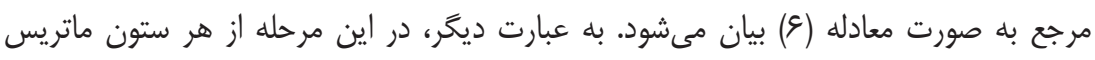

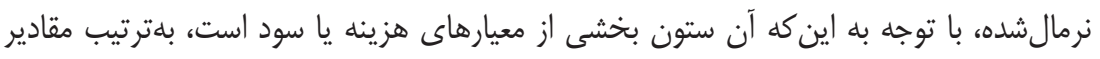
بيشينه و كمينه انتخاب مىشوند.

$r= \begin{cases}\max _{i} x_{i j}^{*}, j \leq g, \\ \min _{i} x_{i j}^{*}, j>g,\end{cases}$ 
$\min _{i}\left\{\max _{j}\left|r_{j}-x_{i j}^{*}\right|\right\}$

رتبلدبنى نمايى به صورت رابطه (V) انتخاب مىشود.

كام ششم: استفاده از الكَوريته ضربى. در اين روش، ضرب مقادير وزنى در ضرايب نرمالشده

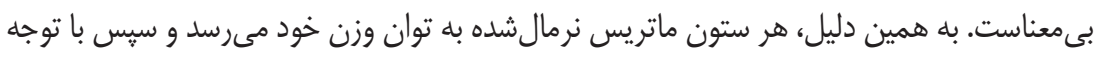
$u_{i}=\frac{\prod_{i=1}^{g}\left(x_{i j}^{*}\right)^{w j}}{\prod_{j=g+1}^{n}\left(x_{i j}^{*}\right)^{w j}}$ به معادله (^) مقادير محاسبه مئشود. رتبنبندى نمايى به صورت رابطه (9) انتخاب مىشود.

$A_{M F}^{*}=\left\{A_{i} \mid \max _{i} u_{i}\right\}$

كام هفتم: قدم نهايى يس از رتبهبندى با سه تكنيك ييشين رتبهبندى به روش مولتهى مورا

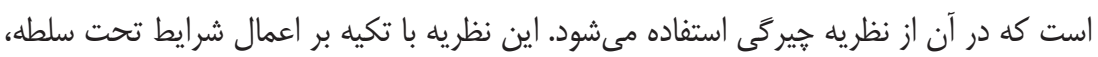
سلطه مَى بر گزينهها، حالت متعدى، برترى و بر بر ابرى استوار است.

\section{تعيين روابط بين شاخصهاى رهبرى}

مدلسازى ساختارى تفسيرى يكى از روشهاى طراحى سيستمها، بلويزه سيستمهاى اقتصادى

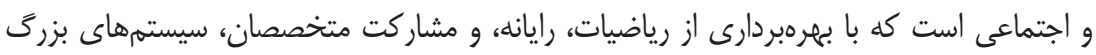
و يبيجيده را طراحى مى كند (ميرغفورى و همكاران، هوسج). اين روش توسط وارفيلد'(19Vץ) ارائه

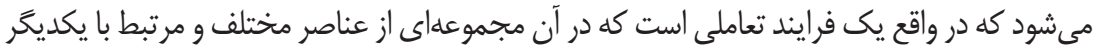
در يك مدل جامع ساختاربندى مىشوند. اين تكنيك به برقرارى نظمه در روابط يِيجيده ميان عناص

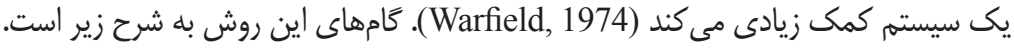

\section{تشكيل ماتريس خودتعاملى ساختارى}

در اين مرحله، عوامل شناسايىشده وارد ماتريس خودتعاملى ساختارى (SSIM) مىشوند.

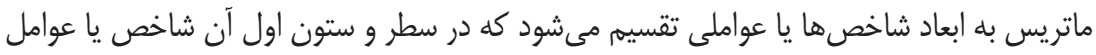

1. Warfield

2. Structural Self-Interaction Matrix 


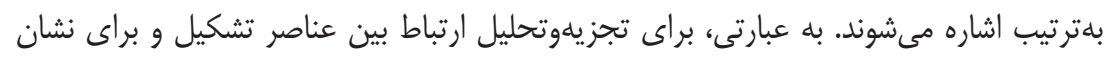

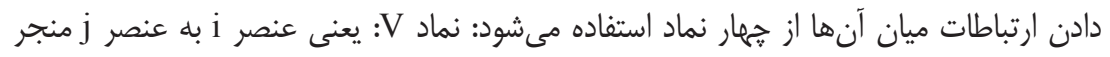

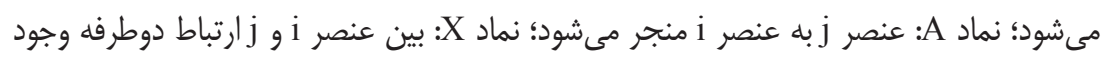
دارد؛ و نماد O: هيج ارتباطى بين عنصر i أ و ز وجود ندارد.

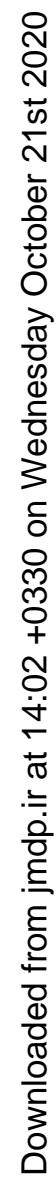

\section{تشكيل ماتريس دستيابى اوليه}

در اين مرحله، با تبديل نمادهاى ماتريس SSIM به اعداد • و ا برحسب قواعد زير مىتوان به ماتريس دستيابى اوليه رسيد:

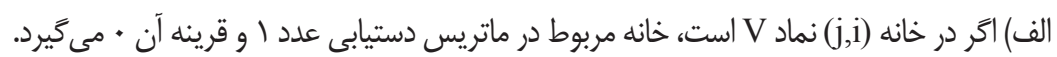

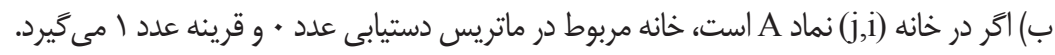

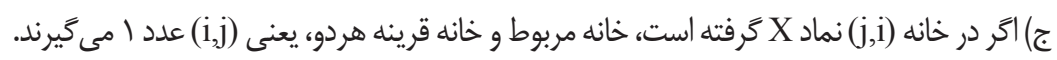

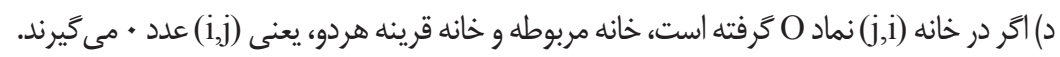

\section{تشكيل ماتريس دستيابى نهايى}

يس إز اين كه ماتريس دستيابى اوليه بددست آمد، بايد ساز كارى درونى آن برقرار شود. براى

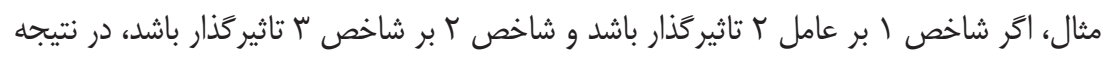

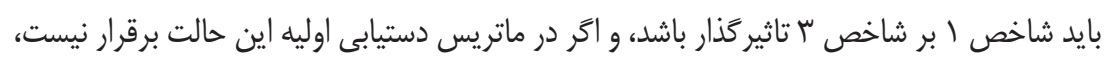

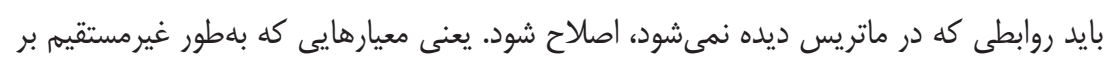

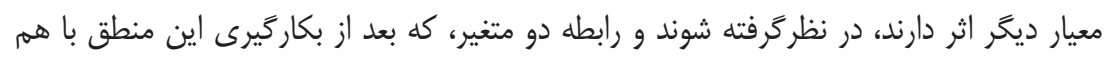
ارتباط يبيدا مى كند، به صورت "ا نمايش داده شود.

\section{تعيين سطح و اولويت متغيرها}

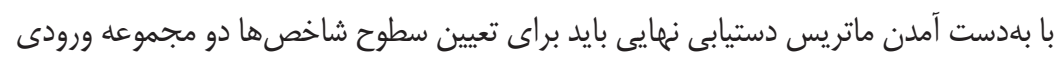

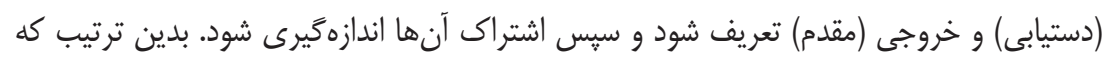

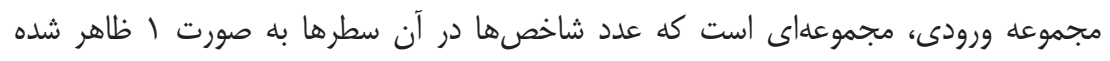

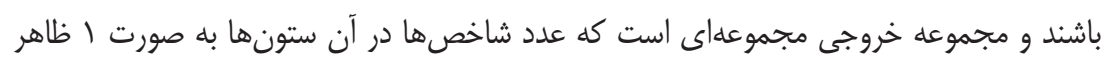

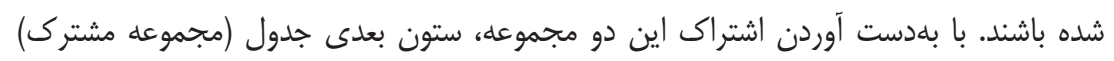


ايجاد مىشود. نخستين سطرى كه اشتراك دو مجموعه برابر با مجموعه خروجى است، سطح

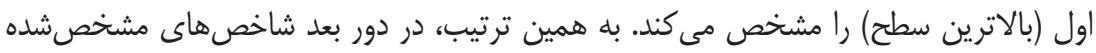
از مجموعه خروجى و ورودى و مجموعه مشترى حذف مىشوند و به همين ترتيب، سطح بعدى دئل شاخص يا شاخصهايى هستند كه مجموعه خروجى آن با مجموعه اشتراك برابر باشند.

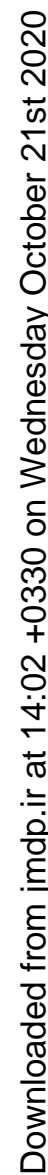

\section{ترسيم مدل ساختارى تفسيرى}

در اين مرحله، مدل بر اساس سطوح تعيينشده و ماتريس دستيابى نهايى رسم مىشود.

نمودار تجزيلوتحليل قدرت نفوذ ـ ميزان وابستكى (MICMAC)

جمع سطرى مقادير دستيابى نهايى براى هر عنصر نشاندهنده ميزان نفوذ، و جمع ستونى

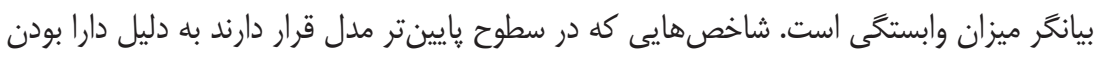
قدرت ييشبرندگى بيشتر به عنوان عوامل ييشبرنده، و عواملى كه در سطوح بالاتر قرار دارند

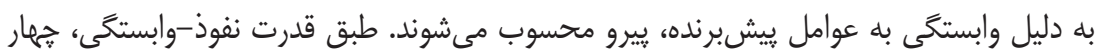
كروه از عناصر قابلشناسايى هستند بود كه عبارتاند از الف. خودمختار: عواملى كه داراى قدرت نفوذ و وابستخى كم هستند؛ ب. مستقل: عواملى كه داراى قدرت نفوذ زياد و وابستخى كم هستند؛

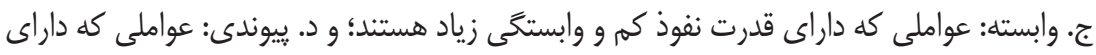
قدرت نفوذ و وابستخى زياد هستند. 


\section{يافتهاى ثئوهش}

\section{شاخص هاى رهبرى}

با بررسى يزوهشهاى بيشين، وع شاخص در سبكهاى رهبرى بهدست مى آيد كه در جدول

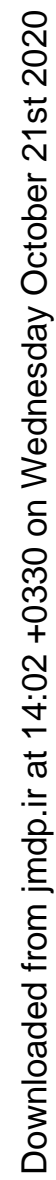

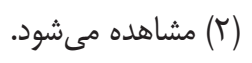

جدول r: شاخصهاى سبككهاى رهبرى

\begin{tabular}{|c|c|c|c|c|c|}
\hline شاخص & شماره & سبكى & شاخص & شماره & سبك : : \\
\hline القاى حس اعتماد به كارامدى سازمان & $1 \wedge$ & \multirow{4}{*}{ تو ت روبرى } & اعتماد به نفس رهبر & 1 & \multirow{5}{*}{ يرجبرى } \\
\hline معنادار كردن شغل & 19 & & شجاعت و شهامت رهبر & r & \\
\hline تصميم گيرى مشار كتى & $r \cdot$ & & خوشخلقى رهبر & r & \\
\hline تفويض اختيار & MI & & قاطعيت رهبر & y & \\
\hline تكريم صادقانه كاركنان & rr & \multirow{5}{*}{ خدمت به مشترى } & توانايى برقرارى ارتباطات رهبر & 0 & \\
\hline تكريم بهموقع كاركنان & r & & تكليف كرايى به كاركنان ناتوان| & 4 & \multirow{2}{*}{ | - متضائى } \\
\hline تكريم حضورى از كاركنان & rf & & رابطه كر ايى با كار كنان بىانكيزه & V & \\
\hline تكريم هرجه مثبت كار كنان & ro & & جهتدهى راهبردى رهبرى & $\wedge$ & \multirow{6}{*}{ 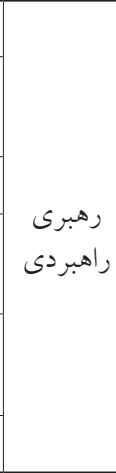 } \\
\hline تكريم مشخص و شفاف از كاركنان & rq & & استفاده رهبر از قابليتهاى & 9 & \\
\hline تهديدهاى محيطى ادراكشده & rV & \multirow{3}{*}{ زهر آكين } & توسعه سرمايه انسانى & $1 \cdot$ & \\
\hline سوء استفاده از شخصيت متزلزل بيرو & r^ & & برقر ارى فرهنخ مشاركت & 11 & \\
\hline برخوردارى رهبر از شخصيت كاركنان & rq & & تاكيد بر رويههاى اخلاقى & ir & \\
\hline صداقت رهبر & $r$. & \multirow{5}{*}{ | اخلاقى } & تدوين كترلهاى راهبردى & 14 & \\
\hline انسجام بخشى رهبر به همكاران & m & & ترغيب ابتكار و خلاقيت & if & \multirow{4}{*}{ رهبرى } \\
\hline تعيين استانداردهاى اخلاقى رهبر & rr & & كاريزما يا نفوذ آرمانى رهبر & 10 & \\
\hline اتخاذ تصميمهاى اخلاقى رهبر & 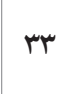 & & ايجاد انخيزش و الهامبخشى دركنان & 19 & \\
\hline حمايت گرى رهبر & ry & & توجه و ملاحظه فردى به كاركنان & IV & \\
\hline
\end{tabular}


ادامه جدول ז: شاخصهاى سبك هاى رهبرى

\begin{tabular}{|c|c|c|c|c|c|}
\hline شاخص & شماره & سبكى & شاخص & شماره & 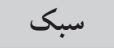 \\
\hline تنوع ايى در جذب نيروى انسانى & $\Delta r$ & \multirow{5}{*}{ ريايدار } & بلد كويى از كاركنان & ro & \multirow{14}{*}{ 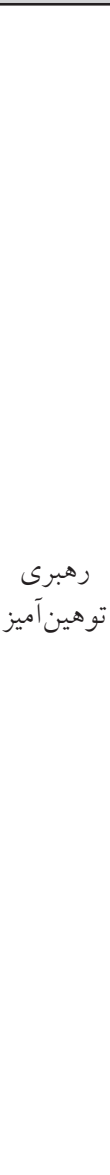 } \\
\hline عدالت سازمانى رهبر & $\Delta \Delta$ & & احمق خواندن كاركنان & me & \\
\hline بالندهازى كار كنان & DS & & خاموشسازى و خفه كردن & rV & \\
\hline | ايجاد تعادل كار و زندكى كاركنان & $\Delta V$ & & $\begin{array}{l}\text { محدود كردن ارتباطات كاركنان } \\
\text { كارن }\end{array}$ & rی & \\
\hline بهبودمحورى در عين يِيشرفت كار & $\Delta \wedge$ & & خالى كردن خشم بر كاركنان & rq & \\
\hline توانايى فردى بالاى رهبر & $\Delta 9$ & \multirow{4}{*}{ رهبرى سنجم } & سوء استفاده از نقاط ضعف & r. & \\
\hline مديرى كار امد و بهرهور & 4. & & ورود به حريم خصوصى كاركنان & +1 & \\
\hline كمكى كننده به اعضا در كار كروهى & 41 & & كممحلى و بى ارزش خواندن & KY & \\
\hline رهبر خلاق جسور & ar & & نقض بيمان با كاركنان & pr & \\
\hline $\begin{array}{c}\text { آكاهى دادن به كاركنان از انتظارهاى عملكردى } \\
\text { آناى }\end{array}$ & gr & \multirow{7}{*}{ 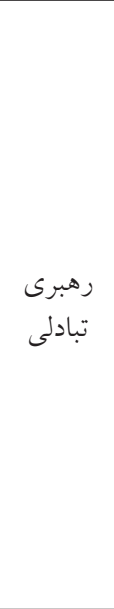 } & فحاشى به كاركنان & KF & \\
\hline $\begin{array}{c}\text { آكاهى رهبر از الزامها و مسائل } \\
\text { كارى كاركنان }\end{array}$ & $9 Y^{c}$ & & تضعيف عزت نفس كاركنان & 40 & \\
\hline آكاهى از ظرفيت هاى كاركنان & 90 & & تمسخر كاركنان & 49 & \\
\hline استفاده از توان كاركنان در حل & 94 & & شرمسار كردن كاركنان & \&V & \\
\hline بها دادن و صرف هزينه براى & $9 V$ & & كوجّك كردن افراد در جمع & $\uparrow \wedge$ & \\
\hline "بيشبرد امور كاركنان بلدون ضرورت & $9 \Lambda$ & & ترجيح منافع ديخران بر خود & $4 q$ & \multirow{5}{*}{ خدمبرى ار } \\
\hline روابط كارى قوى كاركنان با رهبر & 99 & & خدمترسانى به كاركنان & $\Delta \cdot$ & \\
\hline & & & تو اضع و فروتنى با كاركنان & 01 & \\
\hline & & & مهرورزى به كاركنان & Dr & \\
\hline & & & قابليت اعتماد رهبر & Qr & \\
\hline
\end{tabular}




\section{وزن معيارهاى مدل يذيرش فناورى}

طبق مراحل روش بهترين-بدترين، از هر خبره خواسته مىشود كه بهترين و بدترين شاخص

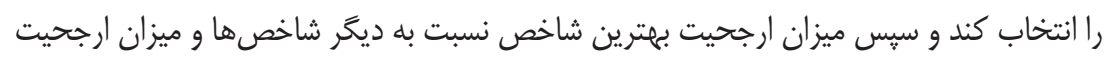

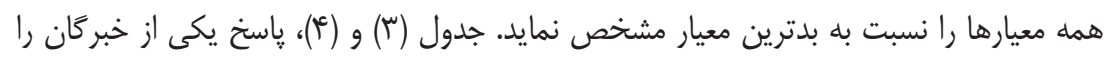

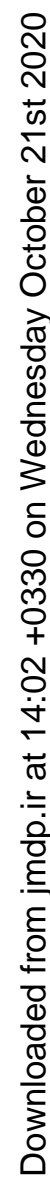
نشان مىدهد.

جدول "اّ: ميزان ارجحيت بهترين معيار نسبت به ديكر معيارها

\begin{tabular}{|c|c|c|c|c|}
\hline تسهيل شرايط C & نفوذ اجتماعى & انتظار تلاش & انتظار عملكرد د & بهتر ين معيار \\
\hline Q & V & $r$ & 1 & انتظار عملكرد \\
\hline
\end{tabular}

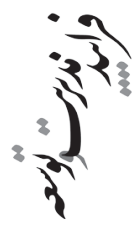

جدول †ز: ميزان ارجحيت همه معيارها نسبت به بدترين معيار

\begin{tabular}{|c|c|}
\hline نفوذ اجتماعى & بدترين معيار \\
\hline v & انتظار عملكرد \\
\hline 0 & انتظار تلاش C \\
\hline 1 & نفوذ اجتماعى C \\
\hline r & تسهيل شرايط C \\
\hline
\end{tabular}

مدل رياضى براى محاسبه وزن معيارها عبارت است از:

$$
\begin{aligned}
& \operatorname{Minz}=\xi \\
& C_{1}-3 C_{2} \leq \xi \\
& C_{1}-7 C_{3} \leq \xi \\
& C_{1}-5 C_{4} \leq \xi \\
& C_{2}-5 C_{3} \leq \xi \\
& C_{4}-3 C_{3} \leq \xi \\
& C_{1}+C_{2}+C_{3}+C_{4}=1 \\
& C_{1}, C_{2}, C_{3}, C_{4} \geq 0
\end{aligned}
$$

با حل مدل بالا، وزن معيارها از نظر خبره اول برابر خواهد بود با: 
جدول ه: وزن معيارهاى مدل يذيرش فناورى

\begin{tabular}{|c|c|}
\hline وزن & معيار \\
\hline$\cdot / 0 \mathrm{VI}$ & انتظار عملكرد \\
\hline - MTS & انتظار تلاش \\
\hline .1 .94 & نفوذ اجتماعى \\
\hline . /ro & تسهيل شرايط \\
\hline
\end{tabular}

با تكرار مراحل بالا براى ساير خبركان، وزن معيارها از نظر آنها محاسبه مىشود. وزن نهايى

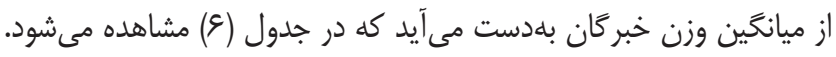

جدول \&: وزن معيارها طبق روش BWM

\begin{tabular}{|c|c|c|c|c|c|c|c|c|c|c|c|}
\hline وزن نهايى & $E_{10}$ & $\mathrm{E}_{9}$ & $\mathrm{E}_{8}$ & $\mathbf{E}_{7}$ & $E_{6}$ & $E_{5}$ & $\mathrm{E}_{4}$ & $\mathbf{E}_{3}$ & $\mathrm{E}_{2}$ & $E_{1}$ & معيار \\
\hline$\cdot / 4 \wedge \Delta$ & $\cdot \pi \cdot \Delta$ & $\cdot / 01 \mathrm{~V}$ & $\cdot / 191$ & $\cdot / A V T$ &.$/ 019$ & $\cdot 10 \cdot \cdot$ & . & .194. & $\cdot / 94$. & $\cdot / \Delta V I$ & انتظار عملكرد \\
\hline$\cdot / \Lambda \wedge$ &.$/ 419$ & $\cdot / \cdot 19$ & $\bullet$ & $.1 .9 \mathrm{~V}$ &.$/ T Y K$ & $\cdot / r \mid 4$ & .1 .0 & 110 & $\cdot / l Q V$ & . TKG & انتظار تلاش \\
\hline $.1 .9 \mathrm{~V}$ & $\cdot / \cdot \wedge r$ &.$/ 199$ & $.1 \cdot 1$ & 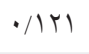 & سזן . & . & .4 & 1.8 & 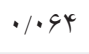 & .1 .94 & ماعى \\
\hline &.$/ 194$ &.$/ 199$ & $\cdot / D K Y$ & • & سזות & $\cdot / r \mid k$ & $\cdot / T \Delta V$ & $\cdot / 1 Q V$ & $\cdot / l Q V$ & ه & تسهيل شرايط \\
\hline
\end{tabular}

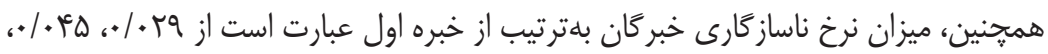

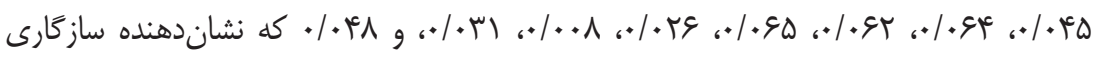

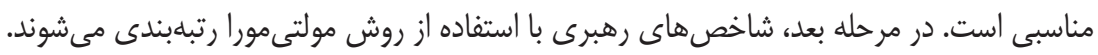
جداول زير اين مراحل را نشان مىدهند.

\begin{tabular}{|c|c|c|c|c|c|}
\hline تسهيل شرايط & نفوذ اجتماعى & انتظار تلاش & انتظار عملكرد & 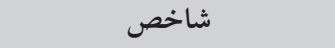 & شماره \\
\hline$r / 9$ & $r / \mu$ & $r / l$ & $T / V$ & اعتماد به نفس رهبر & 1 \\
\hline r & r & $r / 9$ & r & شجاعت و شهامت رهبر & r \\
\hline$r / \mu$ & $r / V$ & r & r & خوش خلقى رهبر & $r$ \\
\hline$:$ & $:$ & $:$ & $:$ & $:$ & : \\
\hline$r / r$ & $r / 9$ & $T / N$ & $r / l$ & تعيين استانداردهاى اخلاقى رهبر & $9 \mathrm{~V}$ \\
\hline$r / l$ & $r / 4$ & $r / 9$ & $r / r$ & اتخاذ تصميمهاى اخلاقى رهبر & $9 \wedge$ \\
\hline T/V & r & $r / q$ & $T / V$ & حمايتخرى رهبر & 99 \\
\hline
\end{tabular}


جدول ^: ماتريس نرمالشده مولتى مورا

\begin{tabular}{|c|c|c|c|c|}
\hline معيار F & معيار r & معيار r & معيار 1 & شاخص \\
\hline$\cdot / M V$ & $\cdot / \mid Q \wedge$ & $\cdot / \mid Q Y$ & $\cdot / M V$ & 1 \\
\hline.$/ 1 k T$ &.$/ 1 k Y$ & ./lky & . / Q & r \\
\hline $.11 \cdot 9$ &.$/ 1 \mathrm{rq}$ &.$/ .99$ & $\cdot / 1 \cdot 1$ & $r$ \\
\hline : & : & : & : & : \\
\hline $.11 \cdot 9$ &.$/ 1 r q$ &.$/ M Y$ & $.11 \cdot 9$ & $9 V$ \\
\hline.$/ .99$ &.$/ 110$ &.$/ 1 T a$ &.$/ 119$ & 91 \\
\hline ./TA &.$/ 1 k F$ &.$/ / k 4$ &.$/ M r V$ & 99 \\
\hline
\end{tabular}

\section{جدول 9: ماتريس نرمال شدهُ موزون}

\begin{tabular}{|c|c|c|c|c|}
\hline معيار F & معيار r & معيار Y & معيار 1 & شاخص \\
\hline.$/ \cdot r T$ &.$/ \cdot 10$ & $\cdot / \cdot r \Lambda$ & .1 .94 & 1 \\
\hline r./. &.$/ .14$ &.$/$ TG & $\cdot / \cdot v^{\mu}$ & r \\
\hline.$/ \cdot T Q$ &.$/ \cdot 1 r$ &.$/ \cdot 11$ & .1 .49 & $r$ \\
\hline : & : & : & : & : \\
\hline.$/ \cdot \Delta \Delta$ &.$/ \cdot 1 r$ & $\cdot / \cdot T^{K}$ & $.1 \cdot 01$ & $9 \mathrm{~V}$ \\
\hline س &.$/ \cdot 11$ & . & $\cdot / \cdot \Delta G$ & 91 \\
\hline $.1 \cdot r q$ & $\cdot / \cdot 14$ & $\cdot / \cdot r q$ & .1 .94 & 99 \\
\hline
\end{tabular}

جدول • ا: رتبهبندى نهايى شاخصها طبق كامهاى جهارم تا هفتم مولتىمورا

\begin{tabular}{|c|c|c|c|c|}
\hline نهايى رتبه & ضر الخوريتم اساس & نقط الخوريتم اساس & جراس الكوريتم & 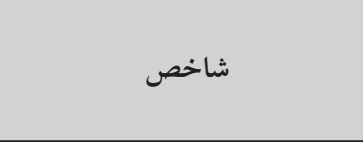 \\
\hline 1 & 1 & 1 & 1 & جهت دهى راهبردى رهبرى \\
\hline r & 0 & r & r & معنادار كردن شغل \\
\hline r & r & r & r & توانيى برقرارى ارتباطات رهبر \\
\hline r & r & r & r & القاى حس اعتماد به كار امدى سازمان \\
\hline 0 & 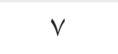 & r & 0 & توسعه سرمايه انسانى \\
\hline 9 & r & $v$ & 9 & استفاده رهبر از قابليتهاى كليدى \\
\hline$v$ & 4 & $v$ & $\checkmark$ & مديريت كارامد و بهرهور \\
\hline
\end{tabular}




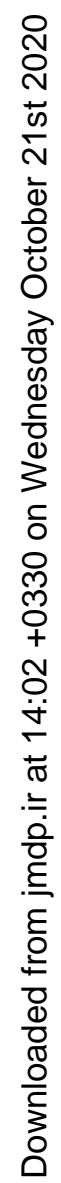

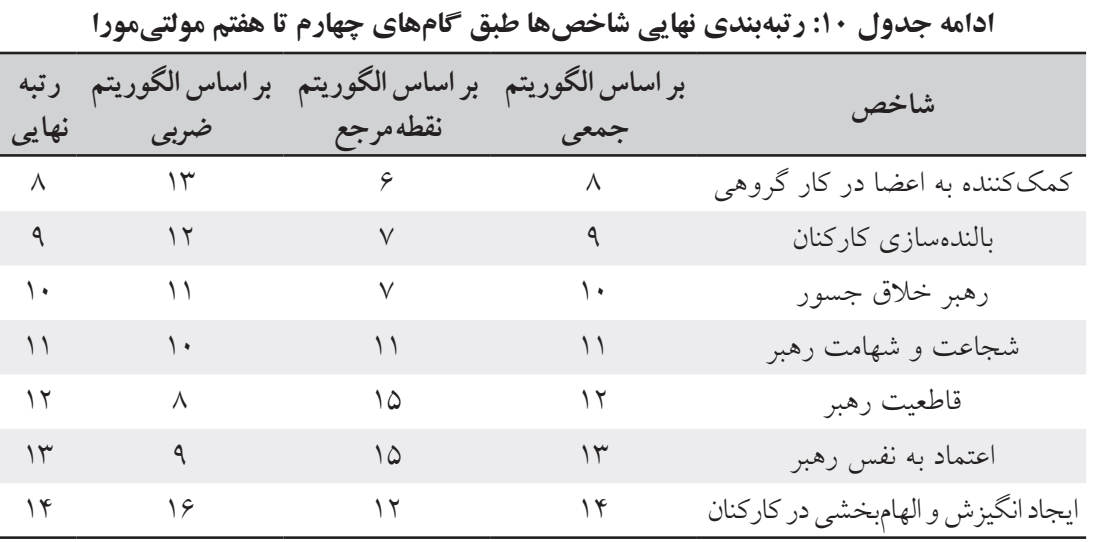

روابط بين عا شاخص برتر، كه به روش قبل مشخص مىشود، با روش مدلسازى ساختارى تفسيرى طبق مراحل زير تعيين مىشود. جدول (I)، نشاندهنده ماتريس خودتعاملى ساختارى با توجه به فراوانى نظرهاى خبر مان است.

جدول 11: ماتريس خودتعاملى ساختارى

\begin{tabular}{|c|c|c|c|c|c|c|c|c|c|c|c|c|c|c|}
\hline If & ir & Ir & 11 & 1. & 9 & $\wedge$ & $v$ & 9 & 0 & $r$ & $r$ & $r$ & 1 & شاخص \\
\hline $\mathrm{V}$ & $\mathrm{V}$ & $X$ & $\mathrm{~V}$ & $\mathrm{~V}$ & $\mathrm{O}$ & $\mathrm{O}$ & $\mathrm{O}$ & $\mathrm{V}$ & $\mathrm{O}$ & V & $X$ & $\mathrm{~V}$ & - & 1 \\
\hline $\mathrm{O}$ & $\mathrm{X}$ & A & $\mathrm{V}$ & $X$ & A & $\mathrm{O}$ & A & $\mathrm{V}$ & $\mathrm{V}$ & A & A & - & & r \\
\hline $\mathrm{V}$ & $\mathrm{V}$ & $\mathrm{X}$ & $\mathrm{O}$ & $\mathrm{V}$ & $\mathrm{V}$ & $\mathrm{V}$ & $\mathrm{O}$ & $\mathrm{O}$ & $\mathrm{O}$ & $\mathrm{O}$ & - & & & r \\
\hline $\mathrm{O}$ & A & $\mathrm{O}$ & $\mathrm{V}$ & $\mathrm{V}$ & $\mathrm{V}$ & $\mathrm{V}$ & $\mathrm{O}$ & $\mathrm{V}$ & $\mathrm{X}$ & - & & & & r \\
\hline $\mathrm{O}$ & $\mathrm{V}$ & A & $\mathrm{V}$ & $X$ & A & $\mathrm{O}$ & $X$ & $X$ & - & & & & & 0 \\
\hline $\mathrm{V}$ & $\mathrm{O}$ & A & $\mathrm{O}$ & $X$ & $\mathrm{O}$ & $X$ & $\mathrm{~V}$ & - & & & & & & 4 \\
\hline $\mathrm{O}$ & A & $\mathrm{O}$ & A & $\mathrm{O}$ & $\mathrm{V}$ & $\mathrm{O}$ & - & & & & & & & V \\
\hline $\mathrm{O}$ & $\mathrm{X}$ & A & $\mathrm{O}$ & $\mathrm{O}$ & $X$ & - & & & & & & & & $\wedge$ \\
\hline$X$ & $\mathrm{~V}$ & A & $\mathrm{X}$ & $\mathrm{O}$ & - & & & & & & & & & 9 \\
\hline $\mathrm{V}$ & $\mathrm{O}$ & $\mathrm{O}$ & $\mathrm{O}$ & - & & & & & & & & & & 1. \\
\hline $\mathrm{O}$ & $\mathrm{V}$ & A & - & & & & & & & & & & & 11 \\
\hline $\mathrm{V}$ & $\mathrm{V}$ & - & & & & & & & & & & & & IT \\
\hline A & - & & & & & & & & & & & & & ir \\
\hline- & & & & & & & & & & & & & & 14 \\
\hline
\end{tabular}


جدول ז ا: ماتريس دستيابى اوليه

\begin{tabular}{|c|c|c|c|c|c|c|c|c|c|c|c|c|c|c|}
\hline If & ir & Ir & 11 & 1. & 9 & $\wedge$ & V & 9 & 0 & r & $r$ & $r$ & 1 & شاخص \\
\hline 1 & 1 & 1 & 1 & 1 & . & . & . & 1 & . & 1 & 1 & 1 & - & 1 \\
\hline
\end{tabular}

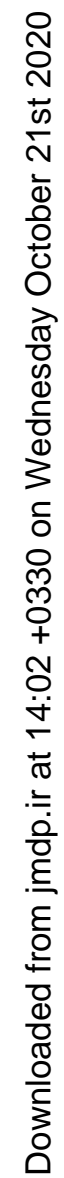

$\begin{array}{lllllllllllllll}\cdot & 1 & \cdot & 1 & 1 & \cdot & \cdot & \cdot & 1 & 1 & \cdot & \cdot & - & \cdot & r \\ 1 & 1 & 1 & \cdot & 1 & 1 & 1 & \cdot & \cdot & \cdot & \cdot & - & 1 & 1 & r\end{array}$
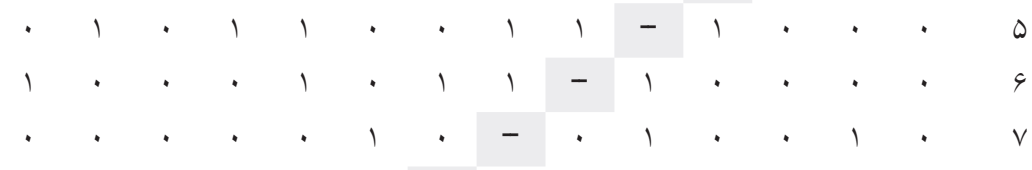

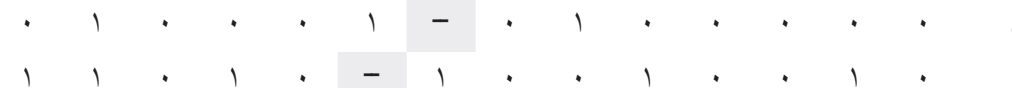

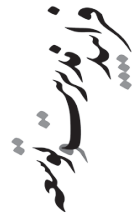

جدول برا: ماتريس دستيابى نهايى

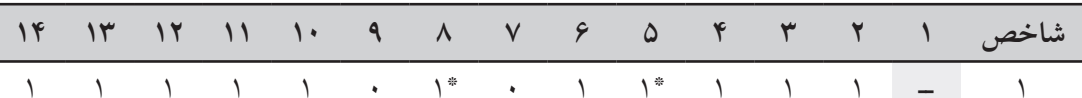

3
3
3
3
3
3
3

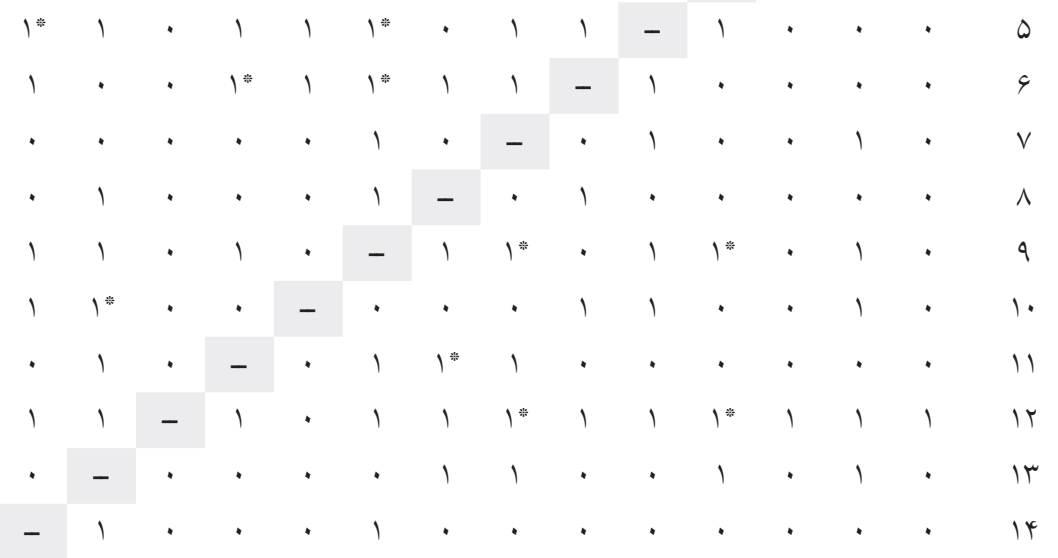




\begin{tabular}{|c|c|c|c|c|}
\hline سطع & مجموعه مشتر ى & مجموعه ورودى & مجموعه خروجى & شاخص \\
\hline & r & r & 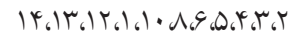 & 1 \\
\hline & $\left.1 r_{6} 1 \cdot .96 \mathrm{~V}\right)^{t}$ & $\left|r_{6}\right| t_{6}\left|\cdot a_{6} V_{6} t_{6}\right|$ & 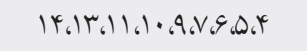 & r \\
\hline & $\left|Y_{6}\right|$ & $\left|Y_{6}\right|$ & $\left|Y_{6} \| T_{6}\right| Y_{6}\left|\cdot q_{6} \Lambda_{6} T_{6}\right|$ & r \\
\hline & Ir.9.0، & $\left|r_{6}\right| r_{6}\left|1.96 \Delta_{6} r_{6}\right|$ & 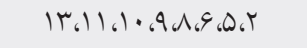 & f \\
\hline & $1 \cdot .9 .6 .9 .4$ & $\left|r_{6}\right| \cdot q_{6} V_{6} g_{6} t_{6} T_{6} \mid$ & $14_{6} 11_{6} 11.1 \cdot 9.96 .964$ & 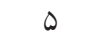 \\
\hline & $\left|r_{6}\right| \cdot ৯ ، \Delta$ & $\left|r_{6}\right| \cdot \Lambda_{6} \Delta_{6} Y_{6} r_{6} \mid$ & $14.1161 \cdot 99 \wedge . V ، 0$ & 9 \\
\hline 1 & Q. Q ( ) & 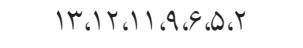 & $9.0, r$ & V \\
\hline \multirow[t]{7}{*}{1} & $1 \% .9 .9$ & 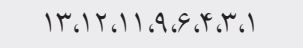 & $1 \% .9 .9$ & $\wedge$ \\
\hline & $\left\|f_{6}\right\| \mathcal{N}_{6} V_{6} \omega_{6} t_{6} t$ & $\left\|Y_{6} \mid T_{6}\right\| \Lambda_{6} V g_{6} \omega_{6} \varphi_{6} \sigma_{6}$ & 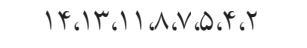 & 9 \\
\hline & 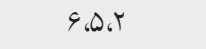 & 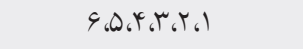 & $\left|Y_{6}\right| \mu_{G} G_{6} \Delta, r$ & $1 \cdot$ \\
\hline & 9 & $\left|r_{6} 9_{6} g_{6} \omega_{6} Y_{6} Y_{6}\right|$ & $1 \mu_{.9} \Lambda_{6}, \mathrm{~V}$ & 11 \\
\hline & $r_{6}$ & ral & 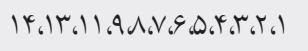 & Ir \\
\hline & 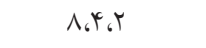 & 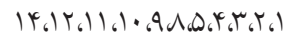 & $N_{6} V_{6} \varphi_{6} T^{\prime}$ & Ir \\
\hline & 9 & $\left|r_{6}\right| \cdot q_{،} q_{6} \Delta_{6} r_{6} r_{6} \mid$ & 14.9 & If \\
\hline
\end{tabular}

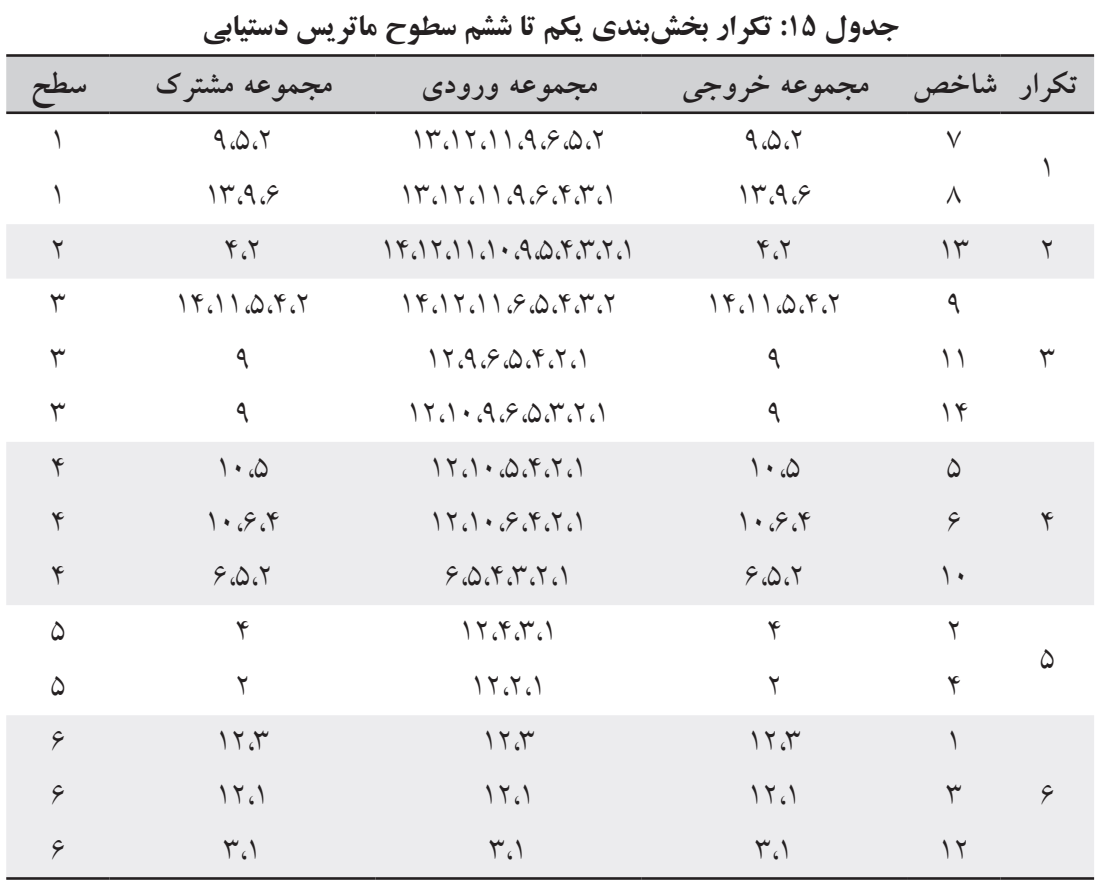


در اين مرحله، بر اساس سطوح تعيينشده و ماتريس دستيابى نهايى، مدل رسم مىشود.

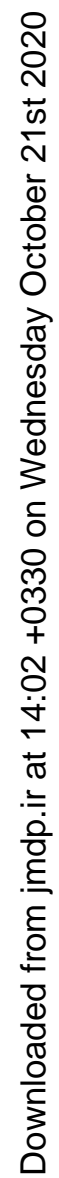

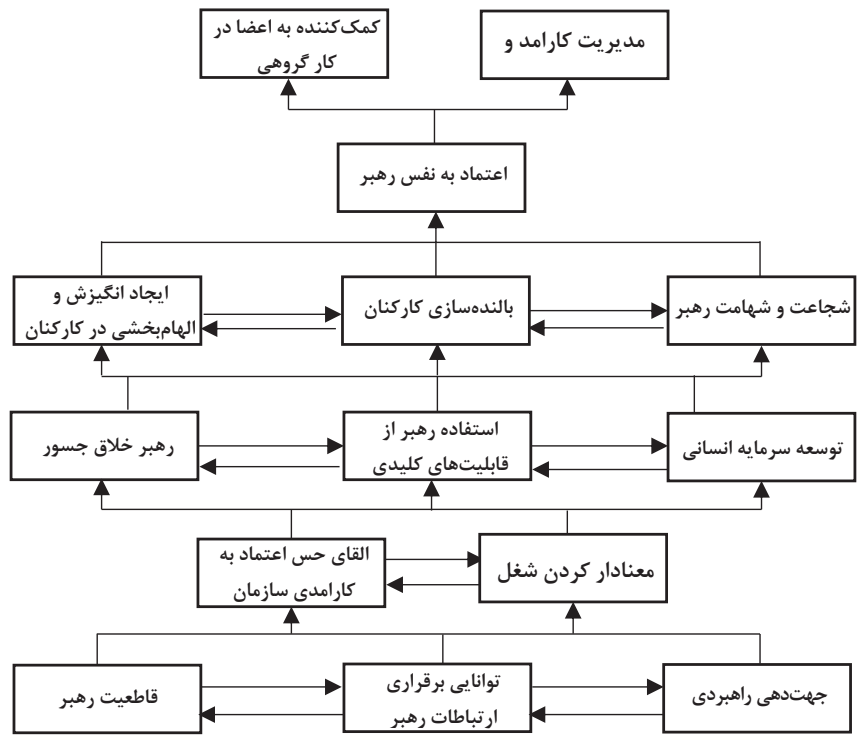

شكل זّ: مدل ساختارى تفسيرى شاخصهاى سبك هاى رهبرى

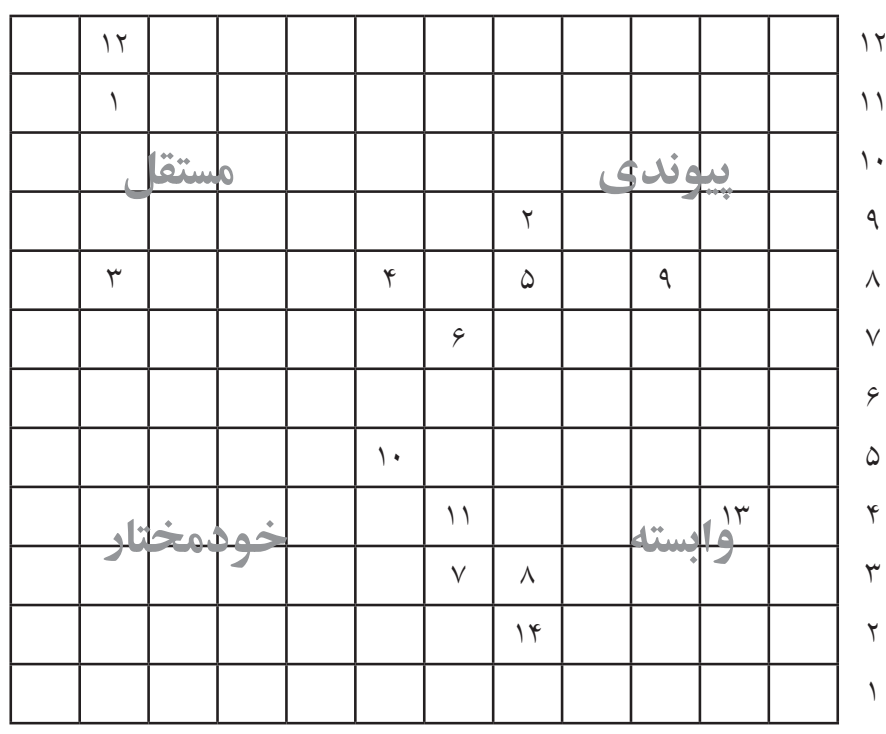

ميزان وابستخى

شكل ث+: نمودار قدرت نفوذ-وابستى 


\section{و نتيجه كيرى}

نياز به نوآورى و تحقق تغييرهاى فناورانه، به رهبرانى با مدلهاى فكرى و رفتارى جديدى نياز دارد كه بتوانند بر اساس دانش مبتنى بر واقعيتها و تحولهاى روز در حوزه فناورى و نوآورى براى دستيابى به يِيشرفت و تعالى سازمان اقدام كنند. در اين راستا يثوهش حاضر با هدف

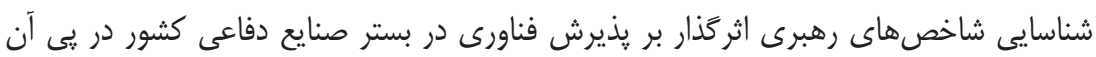
است كه در يك مدل سلسلهمراتبى ظرفيتى را معرفى نمايد كه رهبران سازمان بايد بيشتر بر آن

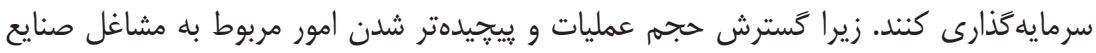
دفاعى، استفاده از فناورىهاى نوين را به امرى اجتنابنايذير تبديل مى كند. از يكسو، يذيرش

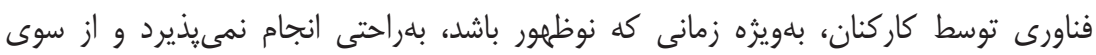

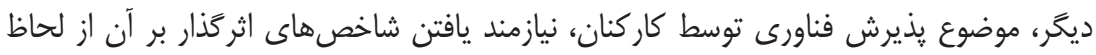

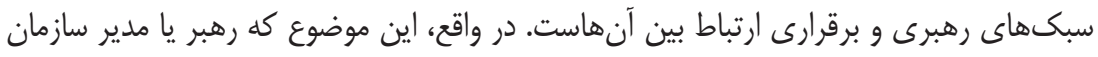
بايد هه اقدامهايى براى فراهم كردن زمينه يذيرش فناورى انجام دهد، تبديل به يك خالش اساسى در دنياى يرتلاطهم و متغير امروزى مىشود كه بهطور سريع فناورىهاى جديدى را تشكيل مىدهد و فناورىهاى قبلى را از دور خارج مى كند. اين يثوهش در ابتدا به بررسى و شناسايى شاخصهاى هر سبك رهبرى مىيردازد. 99 شاخص از سا سبك رهبرى از مبانى نظرى بلددست آورده مى شود. سيس با توجه به محاسبه مقدار

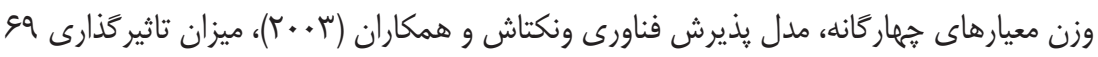
شاخص سبكهاى رهبرى بر اين جهار معيار بررسى مىشوند و با مشخص شدن شاخصهاى برتر،

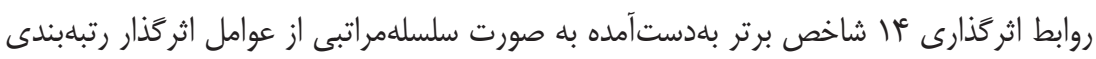
و مدلسازى مىشوند. در وهله نخست، با توجه به نتايج بهدست آمده، مهمترين شاخص يذيرش

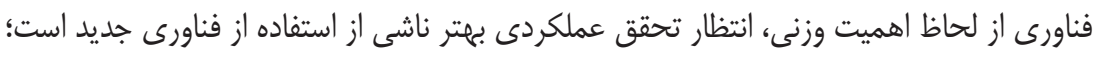
سِّ تسهيل شرايط براى كار كنان در بكارگيرى فناورى، در جايگاه سوم، انتظار ميزان تلاش مورد نياز در استفاده از فناورى، و در يايان، نفوذ اجتماعى ناشى از كار با فناورى است. بنابراين، رهبران براى اثرگذارى بيشتر و سريعتر بر يذيرش فناورى توسط كاركنان، بايد با توجه به اهميت وزنى، شاخصهاى رفتارى رهبرى را بكار گيرند.

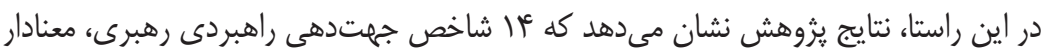
كردن شغل، توانايى برقرارى ارتباطات رهبر، القاى حس اعتماد به كارامدى سازمان، توسعه سرمايه 
انسانى، استفاده رهبر از قابليتهاى كليدى، مديريت كارامد و بهرهور، كمك كننده به اعضا در

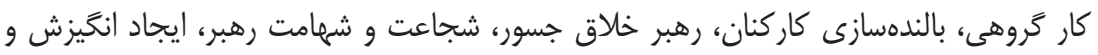

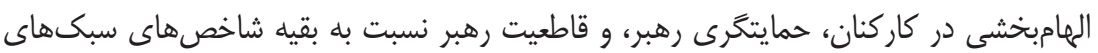
رهبرى، اثركذارى بيشترى بر يذيرش فناورى، با توجه به اهميت وزنى شاخصهاى آنان آن دارد، و

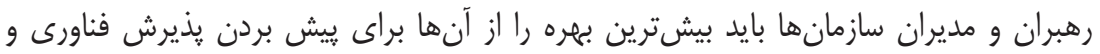
تسهيل آن در كاركنان خود ببرند.

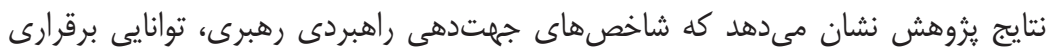

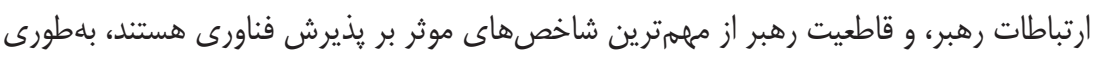

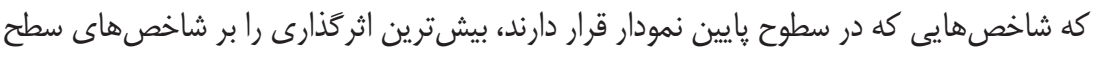

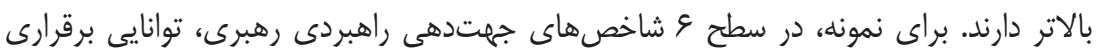

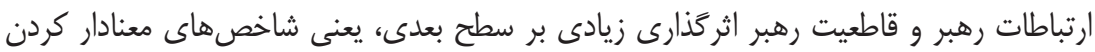

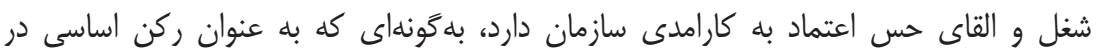
تحقق يذيرش فناورى در سازمان محسوب مىشود. همانطور كه هيت و همكاران'(T) إك) بيان

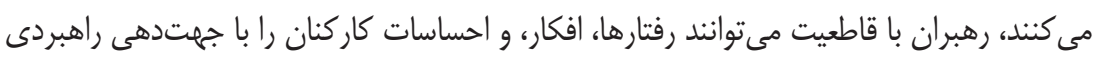

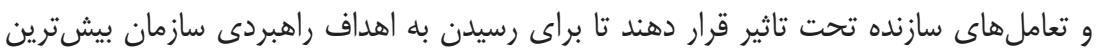
تلاش ممكن را انجام دهند. طبيعى است كه با اين موضوع، حركت به سمت توانمندسازى و تقويت

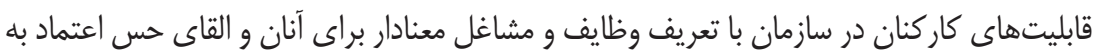

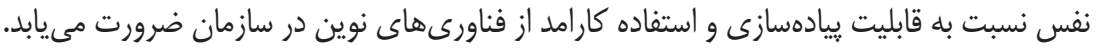
اين فرايند در سه لايحه سلسلهمراتبى با توسعه و تقويت شاخصهاى توسعه سرمايههاى انسانى،

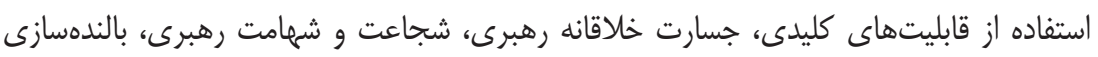

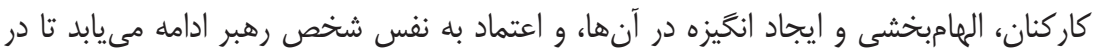

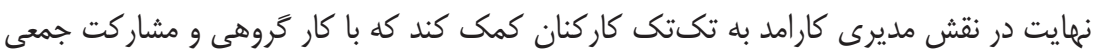

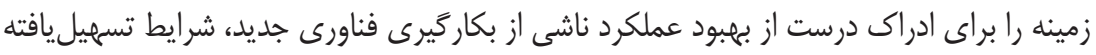

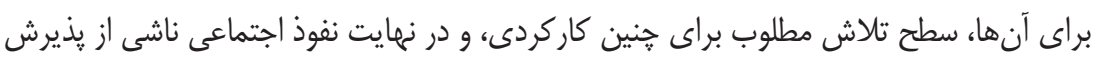
آن فراهم نمايد.

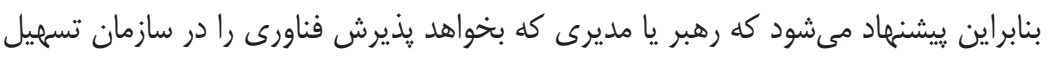
كند، ابتدا مولفههاى شاخصهاى اشارهشده را در خود تقويت كند تا اين تغيير، در رفتار او با با كار كنان

1. Hitt et al. 
نمايان شود و آنها بهخوبى متوجه وجود رفتارهاى اين شاخصها شوند. بدين منظور، مديران بايد

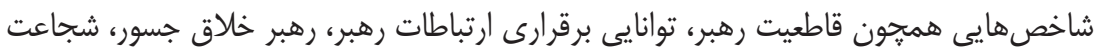

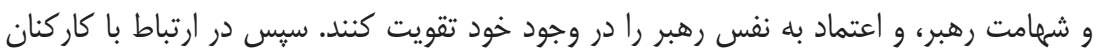
به معنادار كردن شغل، القاى حس اعتماد به كارامدى سازمان، توسعه سرمايه انسانى، بالندهسازى

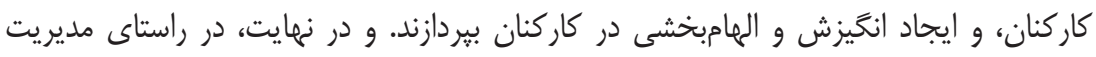

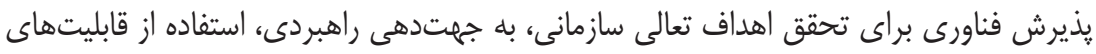

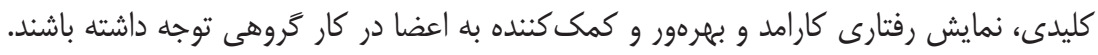

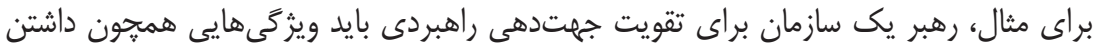
جشه|نداز، ماموريت، و برنامه بلندمدت براى رسيدن به اهداف سازمان داشته باشد و همواره تمام

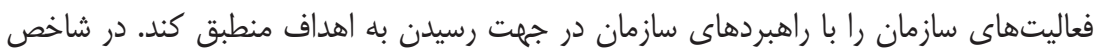

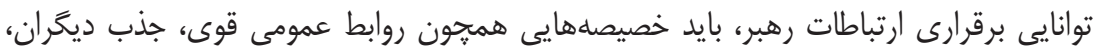

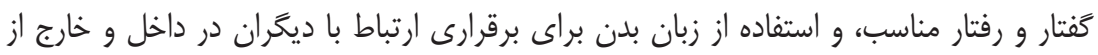

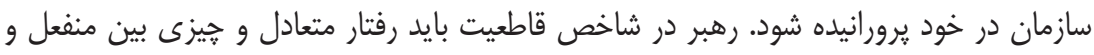

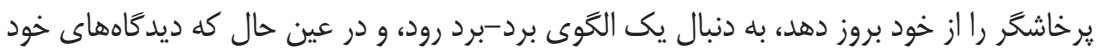

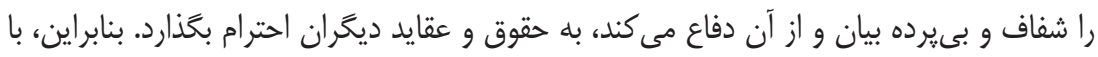

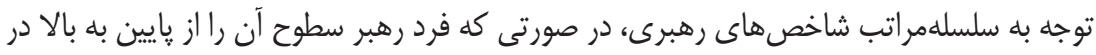
خود تقويت كند، در نهايت به مديرى كارامد و بهرهور و كمك كننده به اعضا در كار كَروهى تبديل

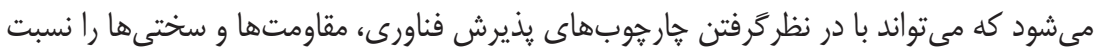

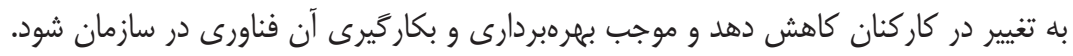

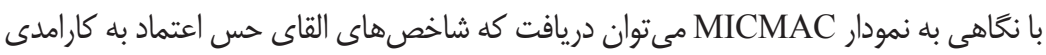

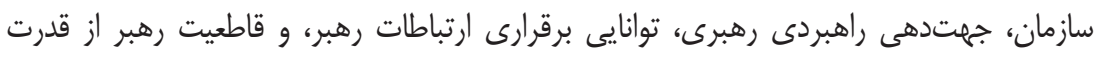

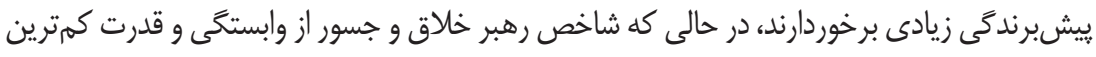

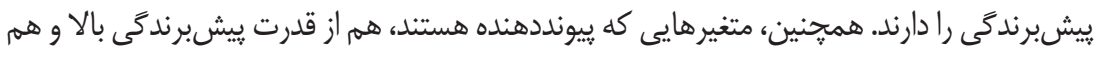

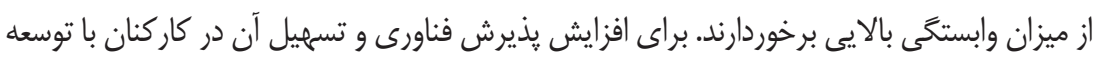

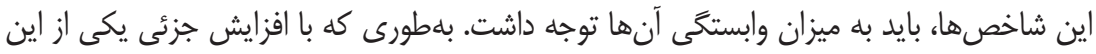

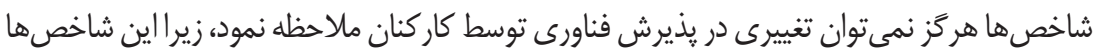

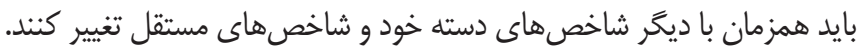

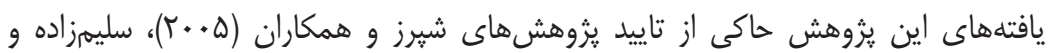




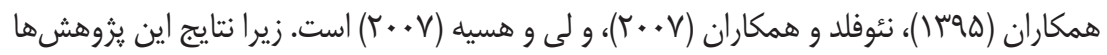

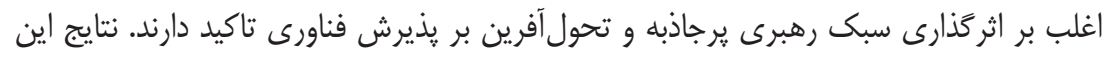

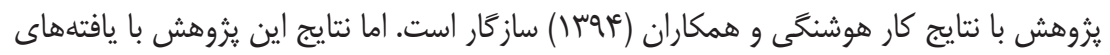
هاشميور (وهجا) كمى متفاوت است. رهبرى يرجاذبه يا كاريزماتيك بر يذيرش فناورى تاثير

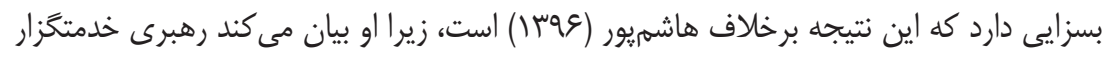
بر يذيرش فناورى اثركذار است، اما در نتايج يزوهش حاضر اين موضوع مشاهده نشد.

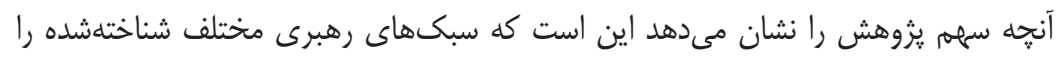

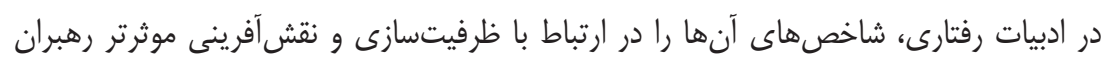

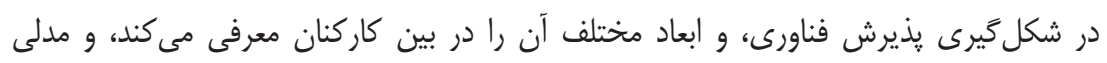

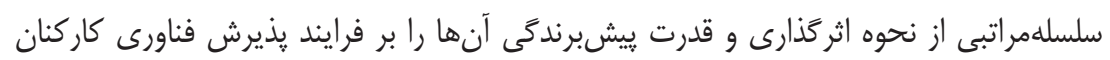

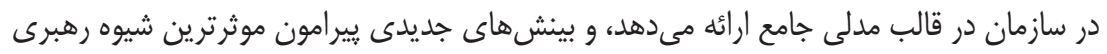

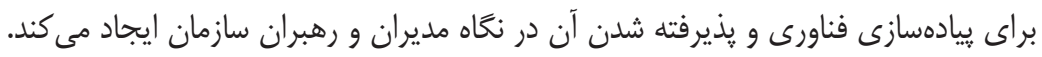

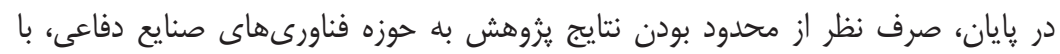

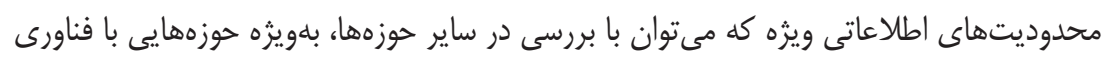

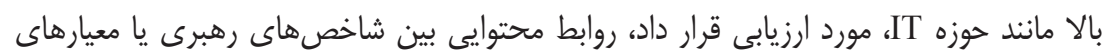

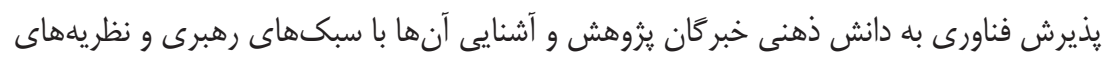

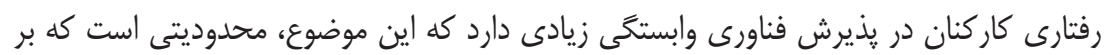

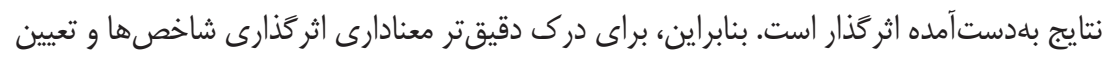

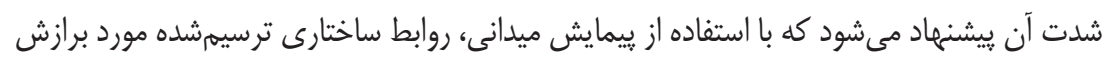

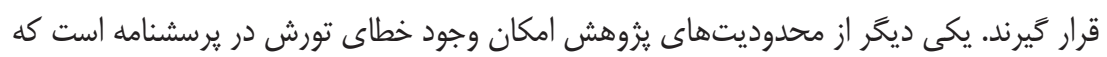
در تحليل نتايج اين يزوهش ارزيابى نشد.

\section{منابع}

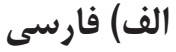

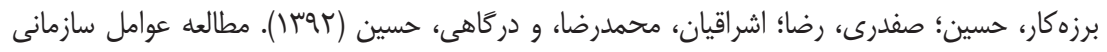

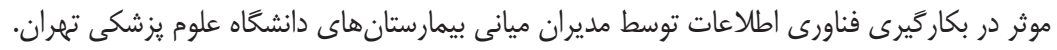

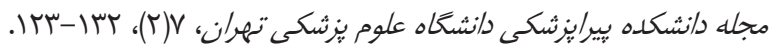

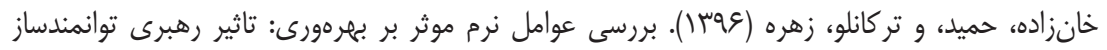


بر انخيزش ييشرفت و انخيزش الهام بخش و ترغيب ذهنى. فصلنامه مديريت بهروورى، •(|(5)،

IIITV

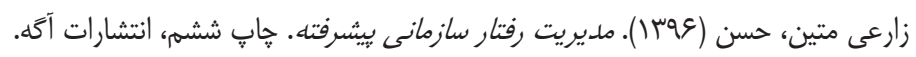

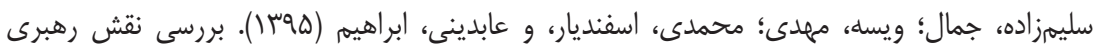

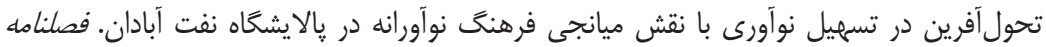

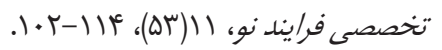

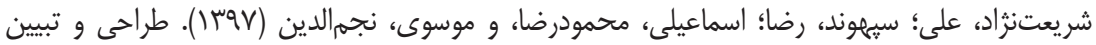

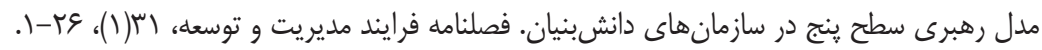

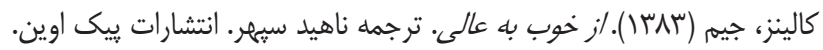

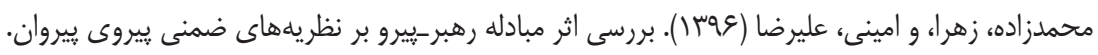

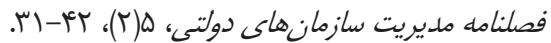

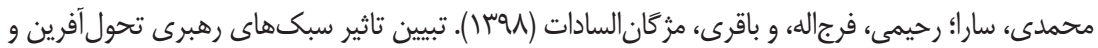

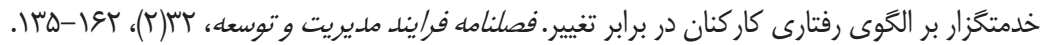

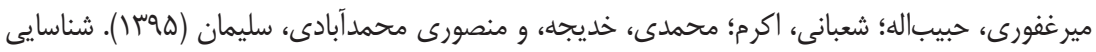

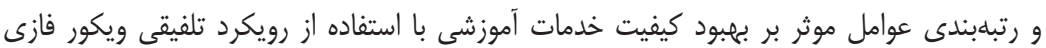

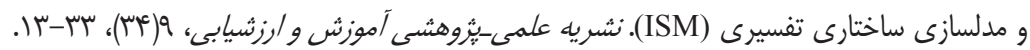

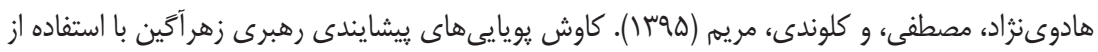

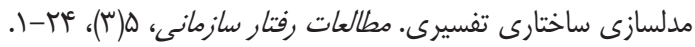

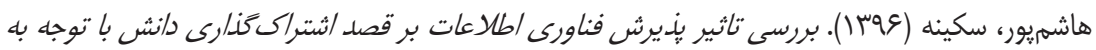

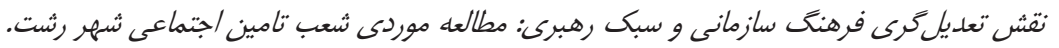

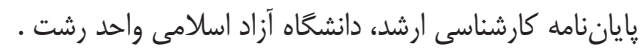

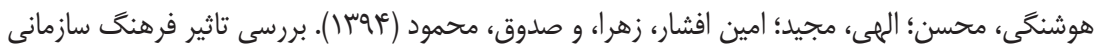

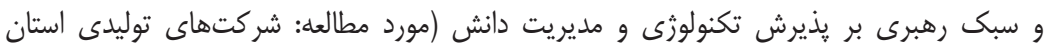

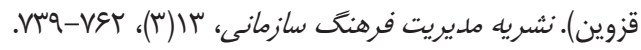

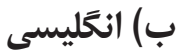

Avey, J. B., Palanski, M. E., \& Walumbwa, F. O. (2011). When Leadership Goes Unnoticed: The Moderating Role of Follower Self-Esteem on the Relationship between Ethical Leadership and Follower Behavior. Journal of Business Ethics, 98(4), 573-582.

Brauers, W. K. M., \& Zavadskas, E. K. (2012). Robustness of Multimoora: A Method for Multi-Objective Optimization. Informatica, 23(1), 1-25.

Brown, M. E., Treviño, L. K., \& Harrison, D. A. (2005). Ethical Leadership:

A Social Learning Perspective for Construct Development and Testing. 
Organizational Behavior and Human Decision Processes, 97(2), 117-134.

Cavalli-Sforza, V., \& Ortolano, L. (1984). Delphi Forecasts of Land Use:

Transportation Interactions. Journal of Transportation Engineering, 110(3), 324-339.

Çetin, M., Karabay, M. E., \& Efe, M. N. (2012). The Effects of Leadership

Styles and the Communication Competency of Bank Managers on the Employee's Job Satisfaction: The Case of Turkish Banks. Procedia-Social and Behavioral Sciences, 58(1), 227-235.

Chang, M. K., \& Cheung, W. (2001). Determinants of the Intention to Use Internet/WWW at Work: A Confirmatory Study. Information \& Management, 39(1), 1-14.

Clayton, C. (1997). Making Strategy; Learning by Doing. Harvard Business Review, 75(1), 141-156.

Davis, F. D. (1993). User Acceptance of Information Technology: System Characteristics, User Perceptions and Behavioral Impacts. International Journal of Man-Machine Studies, 38(3), 475-487.

Davis, F. D., Bagozzi, R. P., \& Warshaw, P. R. (1989). User Acceptance of Computer Technology: A Comparison of Two Theoretical Models. Management Science, 35(8), 982-1003.

Eddleston, K. A., \& Kellermanns, F. W. (2007). Destructive and Productive Family Relationships: A Stewardship Theory Perspective. Journal of Business Venturing, 22(4), 545-565.

Farooq, M., Othman, A., \& Ibrahim, M. B. (2017). Analysing the Relationship between Sustainable Leadership, Talent Management and Organization Health as Predictors of University Transformation. Journal of Positive Management, 8(1), 32-50.

Graen, G. B., \& Uhl-Bien, M. (1995). Relationship-Based Approach to Leadership: Development of Leader-Member Exchange (LMX) Theory of Leadership Over 25 Years: Applying a Multi-Level Multi-Domain Perspective. Leadership Quarterly, 6(2), 219-247.

Hayashi, A., Chen, C., Ryan, T., \& Wu, J. (2004). The Role of Social Presence and Moderating Role of Computer Self Efficacy in Predicting the Continuance Usage of E-Learning Systems. Journal of Information Systems Education, 15(2), 139-154.

Hitt, M. A., Ireland, R. D., \& Hoskisson, R. E. (2012). Strategic Management Cases: Competitiveness and Globalization: Cengage Learning.

Lee, Y., Kozar, K. A., \& Larsen, K. R. (2003). The Technology Acceptance Model: Past, Present, and Future. Communications of the Association for 
Information Systems, 12(1), 752-780.

Li, X., \& Hsieh, J. P.-A. (2007). Impact of Transformational Leadership on System Exploration in the Mandatory Organizational Context (1605609765). Association for Information Systems (AIS): 1-20.

Liao, C., Palvia, P., \& Chen, J.-L. (2009). Information Technology Adoption Behavior Life Cycle: Toward a Technology Continuance Theory (TCT). International Journal of Information Management, 29(4), 309-320.

Mullen, P. M. (2003). Delphi: Myths and Reality. Journal of Health Organization and Management, 17(1), 37-52.

Neufeld, D. J., Dong, L., \& Higgins, C. (2007). Charismatic Leadership and User Acceptance of Information Technology. European Journal of Information Systems, 16(4), 494-510.

Pisapia, J., Reyes-Guerra, D., \& Coukos-Semmel, E. (2005). Developing the Leader's Strategic Mindset: Establishing the Measures. Leadership Review, 5(1), 41-68.

Resick, C. J., Hanges, P. J., Dickson, M. W., \& Mitchelson, J. K. (2006). A Cross-Cultural Examination of the Endorsement of Ethical Leadership. Journal of Business Ethics, 63(4), 345-359.

Rezaei, J. (2016). Best-Worst Multi-Criteria Decision-Making Method: Some Properties and a Linear Model. Omega, 64(1), 126-130.

Rezaei, J. (2015). Best-Worst Multi-Criteria Decision-Making Method. Omega, 53(1), 49-57.

Miri, A., Rangriz, H., \& Sabzikaran, E. (2011). The Relationship between Organizational Structure and Employees' Empowerment in National Iranian Oil Products Distribution Company. Kuwait Chapter of Arabian Journal of Business and Management Review, 33(831), 1-18.

Schepers, J., Wetzels, M., \& de Ruyter, K. (2005). Leadership Styles in Technology Acceptance: Do Followers Practice What Leaders Preach? Managing Service Quality, 15(6), 496-508.

Sun, H., \& Zhang, P. (2006). The Role of Moderating Factors in User Technology Acceptance. International Journal of Human-Computer Studies, 64(2), 5378.

Tepper, B. J. (2000). Consequences of Abusive Supervision. Academy of Management Journal, 43(2), 178-190.

Venkatesh, V., \& Davis, F. D. (2000). A Theoretical Extension of the Technology Acceptance Model: Four Longitudinal Field Studies. Management Science, 46(2), 186-204.

Venkatesh, V., Morris, M. G., Davis, G. B., \& Davis, F. D. (2003). User Acceptance of Information Technology: Toward a Unified View. MIS 
Quarterly, 27(3), 425-478.

Wang, Y. S., Wang, Y. M., Lin, H. H., \& Tang, T. I. (2003). Determinants of User Acceptance of Internet Banking: An Empirical Study. International Journal of Service Industry Management, 14(5), 501-519.

Warfield, J. N. (1974). Developing Interconnection Matrices in Structural Modeling. IEEE Transactions on Systems, Man, and Cybernetics, 4(1), 81-87.

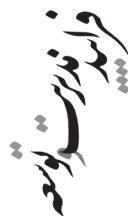

